\title{
Mice Homozygous for a Deletion in the Glaucoma Susceptibility Locus INK4 Show Increased Vulnerability of Retinal Ganglion Cells to Elevated Intraocular Pressure
}

\author{
Shan Gao ${ }^{* \dagger}$ and Tatjana C. Jakobs
}

From the Department of Ophthalmology,* The First Affiliated Hospital, Xi'an Jiaotong University Health Science Center, Xi'an, Shaanxi, China; and the Department of Ophthalmology, ${ }^{\dagger}$ Massachusetts Eye and Ear Infirmary/Schepens Eye Research Institute, Harvard Medical School, Boston, Massachusetts

\author{
Accepted for publication \\ November 17, 2015. \\ Address correspondence to \\ Tatjana C. Jakobs, M.D., \\ Schepens Eye Research Insti- \\ tute, 20 Staniford St., Boston, \\ MA 02114. E-mail: tatjana \\ jakobs@meei.harvard.edu.
}

\begin{abstract}
A genomic region located on chromosome $9 p 21$ is associated with primary open-angle glaucoma and normal tension glaucoma in genome-wide association studies. The genomic region contains the gene for a long noncoding RNA called CDKN2B-AS, two genes that code for cyclin-dependent kinase inhibitors $2 \mathrm{~A}$ and $2 \mathrm{~B}\left(\mathrm{CDKN} 2 \mathrm{~A} / \mathrm{p} 16^{\mathrm{INK} 4 \mathrm{~A}}\right.$ and $\left.\mathrm{CDKN} 2 \mathrm{~B} / \mathrm{p} 15^{\mathrm{INK} 4 \mathrm{~B}}\right)$ and an additional protein ( $\left.\mathrm{p} 14^{\mathrm{ARF}}\right)$. We used a transgenic mouse model in which $70 \mathrm{~kb}$ of murine chromosome 4, syntenic to human chromosome 9p21, are deleted to study whether this deletion leads to a discernible phenotype in ocular structures implicated in glaucoma. Homozygous mice of this strain were previously reported to show persistent hyperplastic primary vitreous. Fundus photography and optical coherence tomography confirmed that finding but showed no abnormalities for heterozygous mice. Optokinetic response, eletroretinogram, and histology indicated that the heterozygous and mutant retinas were normal functionally and morphologically, whereas glial cells were activated in the retina and optic nerve head of mutant eyes. In quantitative PCR, CDKN2B expression was reduced by approximately $50 \%$ in the heterozygous mice and by $90 \%$ in the homozygous mice, which suggested that the CDKN2B knock down had no deleterious consequences for the retina under normal conditions. However, compared with wild-type and heterozygous animals, the homozygous mice are more vulnerable to retinal ganglion cell loss in response to elevated intraocular pressure. (Am J Pathol 2016, 186: 985-1005; http://dx.doi.org/10.1016/j.ajpath.2015.11.026)
\end{abstract}

Family history is a major risk factor for the development of primary open-angle glaucoma (POAG), ${ }^{1}$ but the search for genes that influence disease susceptibility has been difficult. Several genes that are known to cause rare early onset familiar forms of glaucoma, such as myocilin (MYOC) on chromosome $1 q 21-q 31^{2}$ or optineurin $(O P T N)$ on chromosome 10p14-p15. ${ }^{3}$ However, collectively these genes account for only about $5 \%$ of adult onset POAG. ${ }^{4}$ Most cases are believed to be polygenic in origin or caused by an interplay of genetic and environmental factors. 5,6

The recent decade has brought several systematic attempts to identify genetic loci that may account for most glaucoma cases by genome-wide association studies (GWASs) or other genome-surveying methods such as whole-genome (or whole-exome) sequencing of nuclear or mitochondrial DNA. ${ }^{7-19}$ GWASs can generate falsepositive findings that are not reproducible in further studies, so candidate genomic associations are treated with caution until they have been confirmed in different cohorts and different populations. Several candidate glaucomaassociated loci have stood this test and are now widely accepted to confer a relative risk of developing the disease. ${ }^{20}$ One of these is located on human chromosome 9p21.3,

\footnotetext{
Supported by NIH grants R01EY019703 and R01EY022092, a grant from the Chinese Scholarship Council, and grants from the Massachusetts Lions Eye Research Fund and the Ellison Foundation. The morphology core facility at the Massachusetts Eye and Ear Infirmary/Schepens Eye Research Institute is supported by the NIH core grant for vision research SP30EY003790-34.

Disclosures: None declared.
} 


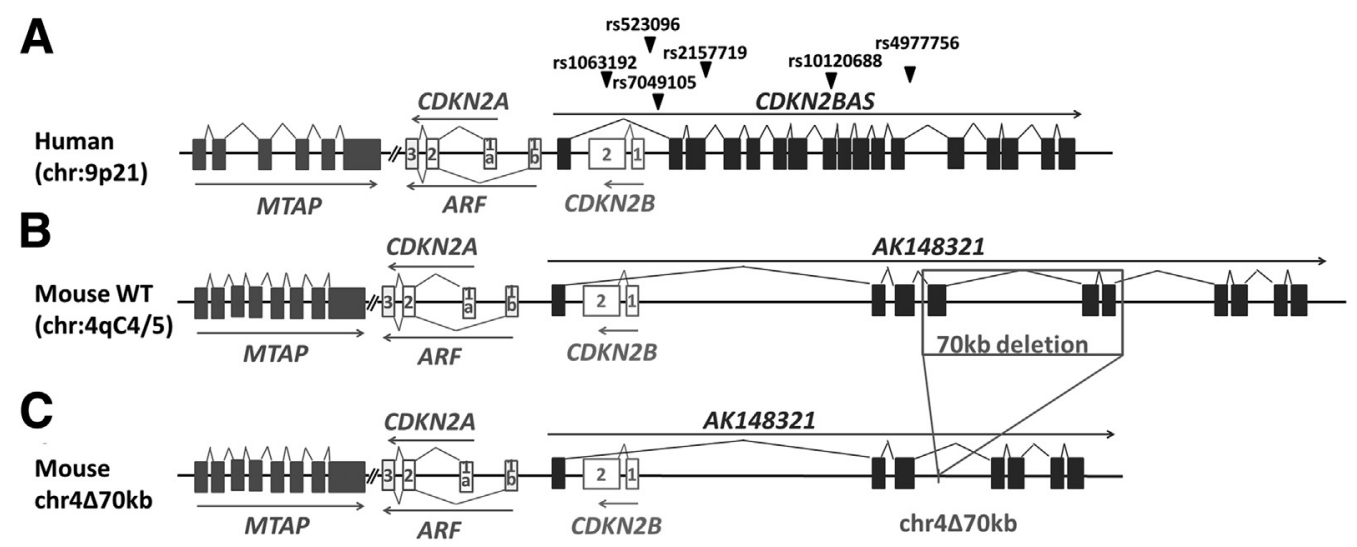

Figure 1 Schematic of CDKN2BAS and adjacent regions on human and mouse. A: Human chromosome 9 p21 region and SNPs found to be most significantly associated with POAG and NTG in GWASs. B: Orthologous region on mouse chromosome 4. A 70-kb deletion area of exon 4 to 6 in AK148321 and adjacent intronic sequences is shown in the box. C: Chr $4 \Delta 70 \mathrm{~kb}$ after targeted deletion. Panel $\mathbf{A}$ is adapted from Ng et al ${ }^{20}$ with permission from John Wiley \& Sons Publishing. The localization of the glaucoma-relevant SNPs was partially adapted from Wiggs et $\mathrm{a}^{14}$ with permission from PLoS. Panel B is adapted from Visel et $\mathrm{a}^{51}$ with permission from Nature Publishing Group. Panel $\mathbf{C}$ is adapted from Chidlow et a $\mathrm{l}^{55}$ with permission from PLoS One. GWAS, genome-wide association study; NTG, normal tension glaucoma; POAG, primary open-angle glaucoma; SNP, single nucleotide polymorphism.

near cyclin-dependent kinase inhibitor $2 \mathrm{~B}(C D K N 2 B)$. It was first reported to be associated with increased vertical cup-to-disc ratio (a known morphometric indicator of glaucoma ${ }^{21}$ ) in a European cohort, ${ }^{12}$ and verified in an American study. ${ }^{22}$ These findings suggested that the same locus is associated with POAG, and several large GWASs on different continents have indeed shown highly significant associations between POAG and single nucleotide polymorphisms (SNPs) on chromosome 9p21.3 in different populations..$^{8-11,14,23}$ The locus was also associated with normal tension glaucoma in several studies, suggesting that genetic variants in this region may primarily affect optic nerve susceptibility in glaucoma. ${ }^{10,14,24,25}$

The Ink4 locus on chromosome 9p21.3 contains several genes (Figure 1). $C D K N 2 A$ and $C D K N 2 B$ are located next to each other in a region of about $80 \mathrm{kB}$ in length. The $C D K N 2 A$ gene also encodes an additional protein, $\mathrm{p} 14^{\mathrm{ARF}}$ (alternative reading frame), that uses an alternative first exon. ${ }^{26}$ Partially overlapping with $C D K N 2 B$ is the gene for a long noncoding RNA that is transcribed in the opposite direction, $C D K N 2 B-A S$ (for antisense), often referred to as ANRIL (antisense noncoding RNA in the Ink4 locus), whose function is not yet well understood. ${ }^{27}$ This arrangement is flanked by the genes for methylthioadenosine phosphorylase $(M T A P)$ and doublesex and Mab3-related transcription factor A1 (DMRTA1). CDKN2A and CDKN2B encode tumor suppressor proteins $\left(\mathrm{p} 16^{\mathrm{INK} 4 \mathrm{~A}}\right.$ and $\mathrm{p} 15^{\mathrm{INK} 4 \mathrm{~B}}$, respectively) that inhibit cell cycle progression by forming complexes with cyclin-dependent kinase (CDK) 4 or CDK6. CDKN2B is upregulated by transforming growth factor (TGF)- $\beta$ and may mediate the growth-arresting activity of this cytokine. ${ }^{28,29}$

Glaucoma was not the first disease to call attention to 9p21.3. Several GWASs have identified the same locus, albeit not usually the same SNPs, as being associated with cardiovascular disease, myocardial infarction, aneurisms, type 2 diabetes, glioma, and other types of cancer. ${ }^{20,30,31}$ Intriguingly, the SNPs associated with POAG that were identified in GWASs localize to the antisense RNA $C D K N 2 B-A S$ or its introns. This raises the question whether $C D K N 2 B-A S$ plays a role in the pathogenesis of glaucoma, and, if so, what the mechanism might be. $C D K N 2 B-A S$ can interact with components of the polycomb repressor complex 1 and 2 and can mediate transcriptional silencing of the Ink4 locus. ${ }^{32}$ Most SNPs fall into the intronic sequences of $C D K N 2 B-A S$ and may influence the expression levels or the splicing pattern of the RNA. ${ }^{14,33}$ Several splice variants of $C D K N 2 B-A S$ have been identified, but their function is as yet unclear. ${ }^{34}$ One of these has been associated with POAG. $^{14}$

Ink4 locus variants may result in dysregulation of $C D K N 2 B-A S$, and subsequent changes in TGF- $\beta$ regulation. Up-regulation of TGF- $\beta 1$ and TGF- $\beta 2$ was reported in glaucomatous tissue from the anterior eye, ${ }^{35,36}$ in the aqueous humor, ${ }^{37-40}$ and in the optic nerve head. ${ }^{41,42}$ The TGF- $\beta 1$ pathway is predicted to be activated in several models of glaucoma and optic nerve damage. ${ }^{43-48}$ Given that TGF- $\beta$ induces the expression of $C D K N 2 B$ and that $C D K N 2 B-A S$ silences the transcription of the Ink4 locus, the two may be functional antagonists; in that case altered expression of $C D K N 2 B$ - $A S$ could lead to increased activity of the CDK inhibitor $C D K N 2 B$, making retinal ganglion cells more vulnerable to apoptosis in glaucoma. ${ }^{20}$ However, other mechanisms are possible. First, $C D K N 2 B-A S$ might also regulate genes outside the Ink4 locus that have an influence on ganglion cell fate. Second, SNPs in this chromosomal region could affect the binding of transcription factors and transcriptional regulators in a manner independent of $C D K N 2 B-A S .^{31,49}$ Finally, SNPs could alter binding sites for microRNAs and thereby disrupt a post-transcriptional regulatory network. ${ }^{50}$

To elucidate the role of the Ink4 locus in cardiovascular disease, Visel et al ${ }^{51}$ created a transgenic mouse model in which $70 \mathrm{kB}$ of the murine chromosome 4 , syntenic to human chromosome $9 \mathrm{p} 21$, are deleted. ${ }^{51}$ This leads to a loss 
of exons 4 to 6 of the murine equivalent to $C D K N 2 B-A S$ (in the mouse called AK148321) (Figure 1, B and C). The homozygous mice $\left(\mathrm{Chr} 4^{\Delta 70 \mathrm{kB} / \Delta 70 \mathrm{kB}}\right)$ were susceptible to developing tumors and gained more weight than their wildtype (WT) littermates, and primary cultures from their aortic smooth muscle cells showed increased proliferation and delayed senescence. ${ }^{51}$ Furthermore, in cardiac tissue the expression levels of $C D K N 2 A$ and $C D K N 2 B$ were significantly reduced. ${ }^{51}$ The homozygous mice were later found to have an ocular phenotype that resembled persistent hyperplastic primary vitreous. ${ }^{52}$ This phenotype may be due to the lower expression of the $\mathrm{p} 14^{\mathrm{ARF}}$ (in the mouse $\mathrm{p} 19^{\mathrm{ARF}}$ ) gene in the developing vitreous, because the $\mathrm{Chr} 4^{\Delta 70 \mathrm{kB} / \Delta 70 \mathrm{kB}}$ mouse phenocopies an ARF knockout. ${ }^{53,54}$

We used the $\mathrm{Chr} 4^{\Delta 70 \mathrm{kB} / \Delta 70 \mathrm{kB}}$ mouse (hereafter referred to as $\triangle 4 \mathrm{C} 4-\mathrm{C} 5)$ to ask whether the deletion of parts of $C D K N 2 B-A S$ (AK148321) leads to discernible phenotype in ocular structures implicated in glaucoma, including the anterior eye, retina, and optic nerve head. In addition, we tested whether mice homozygous or heterozygous (HET) for this deletion show increased susceptibility to elevated intraocular pressure (IOP).

\section{Materials and Methods}

Animals

All animal studies were performed in accordance to the Association for Research in Vision and Ophthalmology guidelines for the Use of Animals in Ophthalmic and Vision Research and were approved by the Institutional Animal Care and Use Committee of the Schepens Eye Research Institute. Mice were group housed under 12-hour dark and light cycles and received water and food ad libitum. The transgenic strain with a 70-kb deletion of murine chromosome $4\left(C h r 4^{470 k B / \Delta 70 k B}\right.$, hereafter referred to as $\left.\Delta 4 \mathrm{C} 4-\mathrm{C} 5\right)$ was obtained from Mutant Mouse Resource and Research Centers at the University of California at Davies [129S6/ SvEvTac-Del (4C4-C5)1Lap/Mmucd, stock no. 032091UCD]. The strain was created by a targeted deletion of 70 $\mathrm{kb}$ on murine chromosome 4 that eliminates exons 4 to 6 of the mouse ortholog of $C D K N 2 B-A S$ (AK148321) and some adjacent intronic sequences. ${ }^{51}$ For a schematic overview see Figure 1, A-C. ${ }^{14,20,51,55}$ The mice are viable and fertile and were maintained as HET breeders to produce homozygous mutant (MUT), HET, and WT offspring. Male and female mice between 3 and 5 months were used.

\section{Genotyping}

PCR products were purified with a fast purification system Nucleospin Extract II (Macherey \& Nagel, Dueren, Germany) for nucleic acids. ${ }^{56}$ The primers used to amplify fragments of the AK148321 gene were as follows: 5'-AAGGTATCCTAAATTGTCTTCTTGCAG-3', 5'-CGAGTCAATTTTCTTCATGTTTATCCTCCA-3'， 5'-CGTAATGTCTATAGGG-
CG- ${ }^{\prime}$, and $5^{\prime}$-TATGAAAGCTTGTGGGCGTGT- ${ }^{\prime}$. The sizes of the amplicons for WT and MUT mice were 180 and $236 \mathrm{bp}$, respectively.

\section{Slit Lamp Photography}

Slit lamp photographic images were captured with an IMAGEnet EZ Lite Software system version 1 (TOPCON, Oakland, NJ). Mice were anesthetized with an intraperitoneal injection of $100 \mathrm{mg} / \mathrm{kg}$ ketamine and $20 \mathrm{mg} / \mathrm{kg}$ xylazine. The doses of ketamine and xylazine are calculated for the mouse's body weight. Their pupils were dilated with $1 \%$ tropicamide (Bausch and Lomb, Tampa, FL).

\section{Fundus Photography}

Fundus photographic images were captured with Micron III retinal imaging system (Phoenix Research Laboratories, Pleasanton, CA). Mice were anesthetized, and their pupils were dilated as described in Slit Lamp Photography. GenTeal gel drops (Alcon, Fort Worth, TX) were used to maintain corneal moisture and clarity.

\section{OCT}

Anterior and posterior segment ultrahigh-resolution optical coherence tomography (OCT) images were obtained with an SD-OCT system (Bioptigen, Morrisville, NC). Mice were anesthetized as described in Slit Lamp Photography. Both averaged single B scan and volume scans were obtained with images centered on optic nerve head (posterior segment) or cornea (anterior segment).

\section{IOP Measurement}

IOP was measured noninvasively in both eyes. After the mouse was anesthetized lightly with isoflurance $(1.5 \%$ delivered via a nosecone), IOP was measured with a rebound tonometer (ICare, Espoo, Finland). The instrument takes five individual measurements and gives the mean as one reading. Five such readings were taken from each eye, and the average was calculated. For microbead injection, IOP was measured 1 day before injection and every 3 to 4 days afterward. Measurements were conducted at the same time in the morning for all genotypes. ${ }^{56}$

\section{Optokinetic Response}

The optomotor reflex-based spatial frequency threshold test was used to estimate the visual acuity of mice. ${ }^{57,58}$ Individual freely moving mice were placed on a 2-inch diameter circular platform located in the middle of an arena surrounded by four computer monitors arranged in a quadrangle. The monitors displayed a moving vertical black and white sinusoidal grating pattern, which mimic a virtual rotating cylinder. Each eye could be tested separately. Clockwise and counterclockwise direction of rotation of the grating provided an independent 
temporal to nasal stimulation of the left and right eye, respectively. Rotation speed $\left(12^{\circ} / \mathrm{sec}\right)$ and contrast $(100 \%)$ were kept constant. Spatial frequencies ranged between 0.02 and 0.46 cycle/degree. Distance between bars ranged between 350 and $11 \mathrm{~mm}$ (Supplemental Table S1). One performer determined the direction of bar rotation and the distance between bars. One observer, who was unable to see the direction of the bars, monitored the tracking behavior of the mouse. Tracking was considered positive when there was a reproducible smooth pursuit of the head or rotation of the body in the direction concordant with the stimulus. The highest spatial frequency tracked in either direction was recorded as the visual acuity. Measurements were conducted blind to the genotype of the mice.

\section{ERG}

Full-field eletroretinogram (ERG) recording was performed with Diagnosys LLC ColorDome system (Lowell, MA) under red dim light $(<600 \mathrm{~nm})$. Animals were dark adapted overnight ( $>12$ hours) and anesthetized, and their pupils were dilated as described in Slit Lamp Photography. Corneal anesthesia was achieved with $0.5 \%$ proparacaine hydrochloride (Akorn, Lake Forest, IL). Signals were recorded in both eyes simultaneously with the use of gold wire loop electrodes (Diagnosys LLC). Active electrodes were precoated with GenTeal gel drops and placed on the center of each cornea. A reference electrode was inserted in the mouth, and a ground electron was inserted into the tail. Mice were placed in front of a Ganzfeld bowl and subjected to a series of increasing-intensity light flashes. ${ }^{59}$

For scotopic threshold response (STR) recordings, 50 to 60 responses were averaged per flash intensity. Intensities ranged from -5.5 to $-3 \log$ cd.s. $\mathrm{m}^{-2}$ with an interstimulus interval of 2 seconds. For scotopic response recordings, 2 to 20 responses were averaged per intensity. Intensities ranged from -3.60 to $2.13 \log$ cd.s.m ${ }^{-2}$ with an interstimulus interval of 5 to 60 seconds between flashes. After completion of the scotopic ERG intensity series, animals were lightadapted for 7 minutes to a steady white background. For photopic flash responses, 25 responses were averaged per flash intensity. Intensities ranged from -1 to $2.01 \mathrm{log}$ cd.s. $\mathrm{m}^{-2}$ with an interstimulus interval of 2 seconds. ${ }^{60}$

One month after IOP elevation induced by microbead injection, STR ERG was performed again under the same conditions to compare the positive STR (pSTR) amplitude loss.

\section{Microbead Injection}

A chronic elevation of IOP was achieved by unilateral anterior chamber injection of $15 \mu \mathrm{m}$ polystyrene microbeads (Invitrogen, Carlsbad, CA). This method was previously used in several studies. ${ }^{61-63}$ After the cornea of anesthetized mice was gently punctured with a 30-1/2-gauge needle, a glass micropipette attached to a Hamilton syringe was inserted into the initial puncture, and positive pressure was applied to create an air bubble. Then the micropipette was removed and reinserted to inject 2 to $3 \mu \mathrm{L}$ of microbeads suspended in phosphate-buffered saline (PBS; final concentration, $2.7 \times 10^{7}$ beads per $\mathrm{mL}$ ). The injected eye of the mouse was kept level for an even distribution of the microbeads within the anterior chamber during the recovery from anesthesia. The uninjected eye served as a contralateral control. PBS $(2-3 \mu \mathrm{L})$ was injected into another batch of 11 mice as a sham control.

\section{Tissue Harvest and Preparation}

Mice were euthanized by carbon dioxide, followed by cervical dislocation, according to procedures approved by institutional animal care and use committee of the Schepens Eye Research Institute. To obtain the eye with the optic nerve without causing structural damage, the skull was opened, and the brain was carefully removed to expose the optic nerve and chiasm. ${ }^{64}$

If the tissue was to be used for histology and immunohistochemistry, the head of the mouse was fixed in $4 \%$ paraformaldehyde for 2 hours at room temperature and then rinsed in PBS. After fixation, the orbital bones, retro bulbar tissue, and ocular muscles were removed to isolate the eyeball and attached optic nerve. The dura surrounding the optic nerve was delicately removed. For histology and hematoxylin and eosin staining, the whole eyeball together with the optic nerve was fixed in $4 \%$ paraformaldehyde at $4^{\circ} \mathrm{C}$ overnight. After rinsing, the tissue was embedded in methacrylate and was sectioned in the mid equatorial through optic disk level. For immunohistochemistry, the cornea was cut off along the limbus, the lens and vitreous were removed, and the sclera and pigment epithelium were peeled away from the neural retina. The optic nerve was gently detached from the retina, and the remaining sclera was removed. The cup-shaped retina and optic nerve head were embedded in $6 \%$ agarose. The unmyelinated portion of the optic nerve was sectioned at $100-\mu \mathrm{m}$ thickness in transverse orientation. The retina was sectioned at $100-\mu \mathrm{m}$ thickness in vertical orientation. For retinal cell counts, four small radial incisions were made in the retina, so that the retina could be flat-mounted ganglion side up on AA nitrocellulose filters (MF-Millipore, Billerica, MA). Sections or whole-mounted retinas were stored in a 24-well tissue culture plate (one section or retina per well) in PBS at $4^{\circ} \mathrm{C}$ until further use. ${ }^{47}$

If the tissue was to be used for paraphenylenediamine staining, the optic nerve was fixed with half-strength Karnovsky's fixative (2\% formaldehyde/ $2.5 \%$ glutaralde-

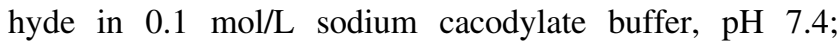
Electron Microscopy Sciences, Hatfield, PA) overnight at $4^{\circ} \mathrm{C}$. Tissue was then rinsed in $0.1 \mathrm{~mol} / \mathrm{L}$ sodium cacodylate buffer and post-fixed with $2 \%$ osmium tetroxide. The tissue was dehydrated in a graded ethanol series and embedded in tEPON-812 resin (Tousimis, Rockville, MD). Semithin sections were cut at $1 \mu \mathrm{m}$. 
If the tissue was to be used for RNA extraction, the eyeball with optic nerve attached was enucleated and dissected in prechilled diethyl pyrocarbonate (Sigma-Aldrich, St. Louis, MO) treated PBS. The retina and the optic nerve were stored in RNAlater (Ambion, Austin, TX) at $4^{\circ} \mathrm{C}$ until further use. ${ }^{65}$

\section{Histology and Immunohistochemistry}

Methacrylate-embedded retina sections were stained with hematoxylin and eosin (Sigma-Aldrich). Agarose retina and optic nerve head sections were incubated in blocking solution (5\% donkey serum, $0.3 \%$ Triton X-100 in PBS) in a 24-well tissue culture plate with gentle shaking for 1 hour at room temperature. Afterward, primary antibodies were applied for 3 to 5 days at room temperature. The primary antibodies used were chicken anti-glial fibrillary acidic protein (GFAP; dilution 1:1000; Abcam, Cambridge, MA), rabbit anti-ionized calcium-binding adaptor molecule 1 (Iba1; dilution 1:200; Wako Pure Chemical Industries, Richmond, VA), rabbit anti- $\beta$-III-tubulin (dilution 1:200; Cell Signaling Technology Inc., Danvers, MA), mouse anti-Brn3a (dilution 1:200; EMD Millipore, Billercia, MA), rabbit anti-Calbindin (dilution 1:100; Swant, Marly, Switzerland), rabbit anti-glutamine synthetase (GS; dilution 1:5000; Sigma-Aldrich), goat anti-choline acetyltransferease (dilution 1:200; EMD Millipore), rabbit anti$\mathrm{PKC} \alpha$ (dilution 1:400; Biosource International, Camarillo, CA), rabbit anti-Recoverin (dilution 1:1000; EMD Millipore), rabbit anti-Synaptophysin (dilution 1:900; Abcam), and rat anti-endomucin (dilution 1:100; Santa Cruz Biotechnology, Inc., Santa Cruz, CA). Sections were washed in PBS and incubated with secondary antibodies conjugated to rhodamine (dilution 1:400; donkey anti-rabbit and donkey anti-mouse), fluorescein isothiocyanate (FITC; dilution 1:400; donkey anti-chicken, and donkey anti-goat), or FITC (dilution 1:400; goat anti-rat IgG; Jackson ImmunoResearch Laboratories, West Grove, PA) overnight at room temperature. Finally, retinas were incubated with the nuclear dye DAPI (Life Technologies, Grand Island, NY) for 10 minutes, washed in PBS, and mounted in Vectashield (Vector Laboratories, Burlingame, CA).

The hematoxylin and eosin-stained slides were imaged with $4 \times, 20 \times$, and $40 \times$ objectives of an Olympus BX51 microscope system (Olympus, Melville, NY). The immunohistochemistry slides were imaged with a $63 \times$ glycerol immersion objective of a Leica TCS SP5 confocal microscope system (Leica Microsystems, Buffalo Grove, IL). The samples were imaged and processed in exactly the same way to ensure the final images between genotypes were comparable. Final images were prepared with the Photoshop CS6 program (Adobe, Waltham, MA).

\section{Retinal Whole Mount Staining and Cell Counts}

For whole retina immunohistochemistry, incubations were also conducted in 24-well tissue culture plates with gentle shaking at $4{ }^{\circ} \mathrm{C}$. Retinas were first blocked in blocking solution (5\% donkey serum, $0.3 \%$ Triton X-100) for 1 hour, followed by incubation in primary antibodies for 3 to 4 days. The primary antibodies used were rabbit anti- $\beta$-III tubulin (dilution 1:200; Cell Signaling Technology Inc.), mouse anti-Brn3a (dilution 1:200; EMD Millipore), rabbit anti-Iba1 (dilution 1:200; Wako Pure Chemical Industries), and rat anti-Endomucin (dilution 1:100; Santa Cruz Biotechnology, Inc.). Subsequently, retinas were washed in PBS and incubated in secondary antibodies conjugated to rhodamine (dilution 1:400; donkey anti-mouse $\operatorname{IgG}$ ), rhodamine (dilution 1:400; donkey anti-rabbit IgG), FITC (dilution 1:400; donkey anti-rabbit $\operatorname{IgG}$ ), or FITC (dilution 1:400; goat anti-rat IgG; Jackson ImmunoResearch Laboratories), for 2 to 3 days. Finally, retinas were incubated with the nuclear dye DAPI (Life Technologies) for $10 \mathrm{mi}-$ nutes, washed in PBS, and mounted in Vectashield (Vector Laboratories). ${ }^{62,66}$

For ganglion cell counting, images of whole mount retinas were acquired on a $63 \times$ glycerol immersion objective of Leica TCS SP5 confocal microscope system (Leica Microsystems). The retina was divided into quadrants, and two mid-peripheral regions (defined as equidistant to the optic nerve head and the border of the retina) were imaged per quadrant, for a total of eight images per retina (246.03 $\mu \mathrm{m}$ by $246.03 \mu \mathrm{m}$ per region in size). Images were obtained as z-stacks (step size, $0.5 \mu \mathrm{m}$ ). All cells in the ganglion cell layer that co-localized with both markers were counted, and the ganglion cell density per retina was obtained. For all eyes of the three genotypes, cells were counted manually by an individual blinded (T.C.J.) to the genotype of the animal in ImageJ software version $1.48 \mathrm{v}$ (NIH, Bethesda, MD; http://imagej.nih.gov/ij). ${ }^{47}$

For the counting of microglial cells, image stacks of wholemounted retinas were acquired on a $20 \times$ (Zoom 1.7) glycerol immersion objective of Leica TCS SP5 confocal microscope system. The retina was also divided into quadrants and one mid-peripheral region was imaged per quadrant, for a total of four images per retina ( $480 \mu \mathrm{m}$ by $480 \mu \mathrm{m}$ per region). Microglial cells were counted manually by an individual blinded (T.C.J.) to the genotype of the animal in ImageJ software.

\section{PPD Staining of Optic Nerve Axons and Injury Evaluation}

Paraphenylene diamine (PPD; MP Biomedicals, Hatfield, PA) stains degenerating and dying axons and has been used for optic nerve grading in glaucomatous animals. ${ }^{67}$ An aqueous solution of $2 \%$ PPD was used to stain semithin cross-sections for 30 minutes. Images were acquired on an Olympus BX51 microscope with $20 \times$ and $100 \times$ objectives. Images from microbead-injected, saline-injected eyes and their contralateral eyes were masked and assessed by two independent observers. A graded scale of nerve injury that ranged from 1 (normal) to 5 (total degeneration) was used. ${ }^{68}$ 
Table 1 Primers Used for Quantitative PCR

\begin{tabular}{|c|c|c|c|}
\hline Primers & GenBank accession no. & Primer sequence $\left(5^{\prime}-3^{\prime}\right)$ & Amplicon size, bp \\
\hline CDKN2A (Exon 1a-2) & NM_001040654 & $\begin{array}{l}\text { Forward: 5'-ATGGAGTCCGCTGCAGACA-3' } \\
\text { Reverse: 5'-ATCATCACCTGAATCGGGGTA-3' }\end{array}$ & 134 \\
\hline$A R F($ Exon $1 \mathrm{~b}-2)$ & NM_009877 & $\begin{array}{l}\text { Forward: 5'-TTCTTGGTGAAGTTCGTGCGATCC-3' } \\
\text { Reverse: 5'-CGTGAACGTTGCCCATCATCATCA-3' }\end{array}$ & 149 \\
\hline$C D K N 2 B$ & NM_007670 & $\begin{array}{l}\text { Forward: } 5^{\prime}-\text { AGATCCCAACGCCCTGAAC }-3^{\prime} \\
\text { Reverse: } 5^{\prime}-\text { TCGTGCACAGGTCTGGTAAG-3' }\end{array}$ & 144 \\
\hline AK148321 (Exon 3) & AK148321 & $\begin{array}{l}\text { Forward: 5'-CAAGGCTGGCACCTGGGTAGATGTT-3' } \\
\text { Reverse: 5'-TGGATGGGAGTGTGGTCTTCGTAGC-3' }\end{array}$ & 127 \\
\hline Tgfb1 & NM_011577 & $\begin{array}{l}\text { Forward: 5'-CTGCTGACCCCCACTGATAC-3' } \\
\text { Reverse: } 5^{\prime}-\text { AGCCCTGTATTCCGTCTCCT-3' }\end{array}$ & 94 \\
\hline Tgfb2 & NM_009367.3 & $\begin{array}{l}\text { Forward: 5'-AGTTCAGACACTCAACACACCAAAG-3' } \\
\text { Reverse: 5'-CATTCCATCGACCCTATCTGA-3' }\end{array}$ & 107 \\
\hline
\end{tabular}

The Nucleotide database is available at http://www.ncbi.nlm.nih.gov/nuccore.

Each eye was then assigned a grade of injury determined by calculating the means of the two independent grade scores.

\section{RNA Extraction and cDNA Preparation}

Total RNA was extracted from retina with the use of the RNeasy plus mini kit (Qiagen, Valencia, CA), whereas the total RNA of the optic nerve was extracted with the RNeasy Plus Micro Kit (Qiagen) because of the small tissue volume, according to the manufacturer's instructions. RNA concentration and quality were assessed on BioAnalyzer 2100 (Agilent Technologies, Santa Clara, CA). Only the RNA samples that had a RNA integrity number higher than 8 (mean, $9.40 \pm 0.42$ ) were used for cDNA synthesis. Twenty nanograms of RNA from the optic nerve and $1.2 \mu \mathrm{g}$ of RNA from the retina were reverse-transcribed with the SuperScript First-Strand Synthesis System (Invitrogen) according to the manufacturer's instructions. cDNA concentration and quality were assessed on NanoDrop 2000 (Fisher Scientific, Pittsburgh, PA). ${ }^{47,65}$ Quality and quantity of total RNA and cDNA are shown in Supplemental Tables S2 and S3.

\section{Quantitative PCR}

The amplified cDNAs of optic nerves and retinas were diluted and used as a template for quantitative PCR. Quantitative PCR was performed with an Applied Biosystems Step One Plus Real-time PCR system and SYBR green master mix (Applied Biosystems, Foster City, CA) in a $10-\mu \mathrm{L}$ reaction volume according to standard procedures. ${ }^{65}$ Melting curve analysis after SYBR green-based detection confirmed the specificity of amplification and the absence of nonspecific amplification and primer dimers. Genomic DNA was removed during RNA extraction with the use of a gDNA Eliminator spin column in the RNeasy
Plus Micro and Mini Kit, and primers that span intron/exon boundaries were used to avoid amplifying genomic DNA. $G A P D H$ was used as a reference gene because the expression level in the retina and optic nerve are stable. The primer set for $A R F$ was taken from a published study, ${ }^{52}$ and the other primers were designed with the primer design tool on the Saccharomyces Genome Database website (http://www. yeastgenome.org/cgi-bin/web-primer, last accessed October 30, 2015). Primer sequences are given in Table 1 .

Five biological replicates were used for each genotype in the normal control eye, and three biological replicates were used after microbead injection. All samples were run in triplicate with nontemplate controls. Because the concentration of total RNA from the retina and optic nerve are different because of the limited amount of tissue in the optic nerve, the dilution of cDNA is 1:10 for the retina and 1:5 for the optic nerve. For the genes in the 9 p21 region, the concentration of primers was $1 \mu \mathrm{mol} / \mathrm{L}$ for the retina and 5 $\mu \mathrm{mol} / \mathrm{L}$ for the optic nerve. For the $T g f b 1$ to $T b f b 3$ genes, the concentration of primers was $0.5 \mu \mathrm{mol} / \mathrm{L}$ because of the low expression levels of the $T g f$ genes. The relative expression of target genes was obtained by the $2^{-\triangle \Delta \mathrm{C}_{\mathrm{T}}}$ method.

\section{Data Analysis}

Mean and SD were calculated, and data of the three types of mice were tested for statistically significant differences by one-way analysis of variance and $t$-tests.

After microbead injection, the IOPs in both eyes were measured twice weekly, and the area under the curve (IOP in $\mathrm{mmHg}$ versus time) was determined with a user-written Matlab routine. This area is referred to as the cumulative IOP (cIOP) because a measure of the total pressure insult the eye was subjected to during the time of the experiment (1 month). We 

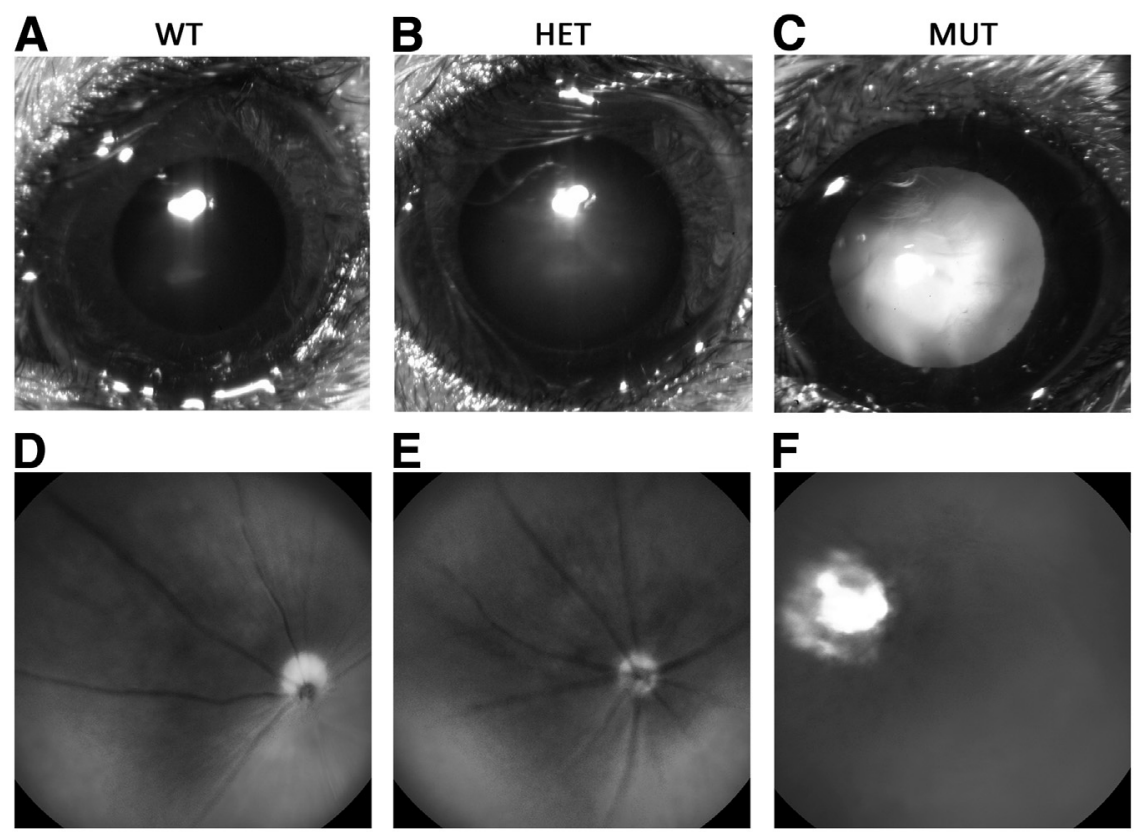

$\mathbf{F}$

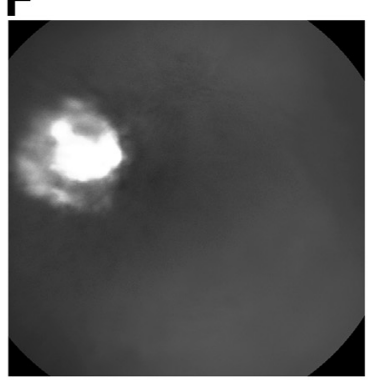

G

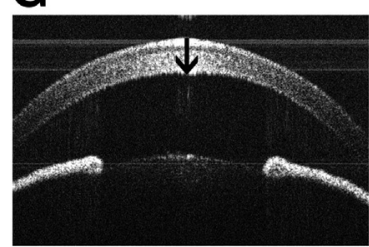

H

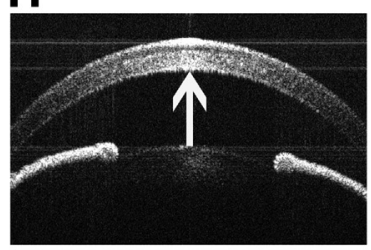

I

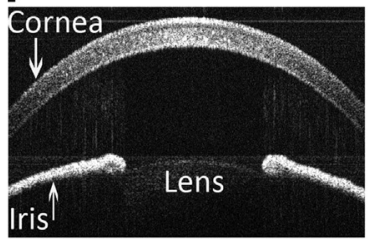

J

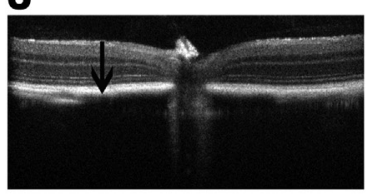

K
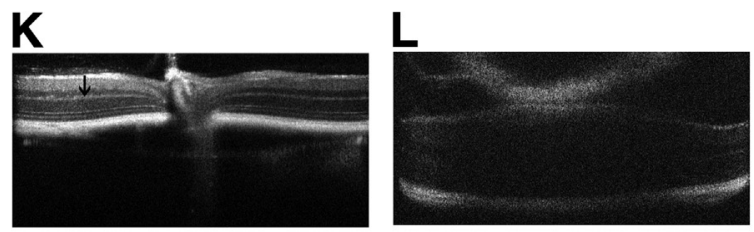

M

$\mathbf{N}$
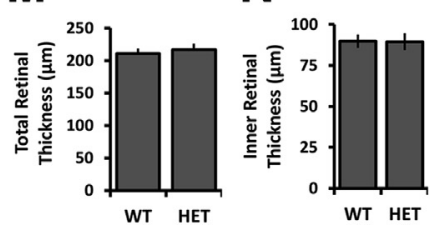

0

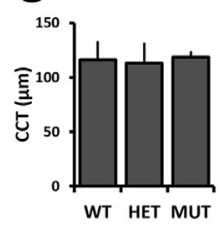

$\mathbf{P}$

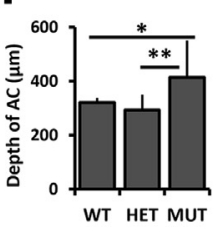

Q

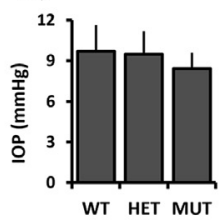

Figure 2 Clinical ocular features of PHPV phenotype in MUT mice. A, D, G, and J: WT; $\mathbf{B}, \mathbf{E}$, H, and K: HET; C, F, I, and L: MUT. A-C: Slit lamp images are normal in WT and HET eyes. The MUT eye is showing normal ocular surface and dense lens opacity. D-F: Fundoscopic images are normal in WT and HET eyes. Lens opacity obscures fundoscopic view in MUT eye. G-I: Anterior segment OCT images are normal in WT and HET eyes. CCT were measured for the whole layer of cornea in the central position (G, arrow), which show no significant difference among each genotype (0). Depth of anterior chamber was measured from the posterior of the cornea to the surface of the lens ( $H$, arrow). The MUT mice have a deeper AC than WT and HET mice (P). J-L: Retinal OCT images are normal in WT and HET mice. Total retinal thickness measured the whole layer of retina (J, arrow). Inner retinal thickness combined ganglion cell layer, inner plexiform layer, and inner nuclear layer ( $K$, arrow). The two thicknesses of the retina have no significant difference ( $M$ and $\mathbf{N}, t$-test). The retinal detail of the MUT eye is blurred, and there is a membrane-like structure attached to the retina (L). Q: IOP of each genotype mice are normal and have no significant difference. Images are representative of 12 eyes per genotype. Data are expressed as means \pm SD. $n=14$ eyes in WT mice, 12 eyes in HET mice, 10 eyes in MUT mice. ${ }^{*} P<0.05,{ }^{* *} P<0.01$ (one-way analysis of variance). AC, anterior chamber; CCT, central corneal thickness; HET, heterozygous; IOP, intraocular pressure; MUT, mutant; OCT, optical coherence tomography; PHPV, persistent hyperplastic primary vitreous; WT, wild-type. then calculated the $\Delta c$ IOP for each animal as the cIOP in the experimental eye minus the cIOP in the contralateral eye. ${ }^{69}$ Ganglion cell loss was correlated with $\Delta$ cIOP to ensure that animals of all genotypes experienced the same amount of pressure injury. Ganglion cell losses after microbead injection were compared with a one-way analysis of variance.

\section{Results}

\section{Clinical Features in $\triangle 4 C 4-C 5$ Mice}

We compared the clinical ocular phenotype of 3- to 5-month-old WT ( $n=14$ eyes), HET ( $n=12$ eyes), and MUT ( $n=10$ eyes) $\Delta 4$ C4-C5 mice. The outward appearances of the WT and HET mice were normal. About one-half of the MUT mice had microphthalmia. Eyes were assessed by slit lamp and fundus photography. Slit lamp examination demonstrated dense lens opacities in the MUT eyes (Figure 2C), whereas WT and HET eyes had normal ocular surface and lens structures (Figure 2, A and B). Lens opacity prevented fundoscopic analysis in MUT eyes (Figure 2F). The HET and WT eyes exhibited normal retinal pigmentation patterns, vascularization, and optic nerve head morphology (Figure 2, D and E).

In OCT, both anterior and posterior segments in the WT and HET eyes were normal (Figure 2, G, H, J, and K). The MUT eyes had normal corneas and irises (Figure 2I), but the retinas could not be imaged in detail because a membranelike structure was attached to the retina and precluded visualization (Figure 2L). Total retinal thickness was 

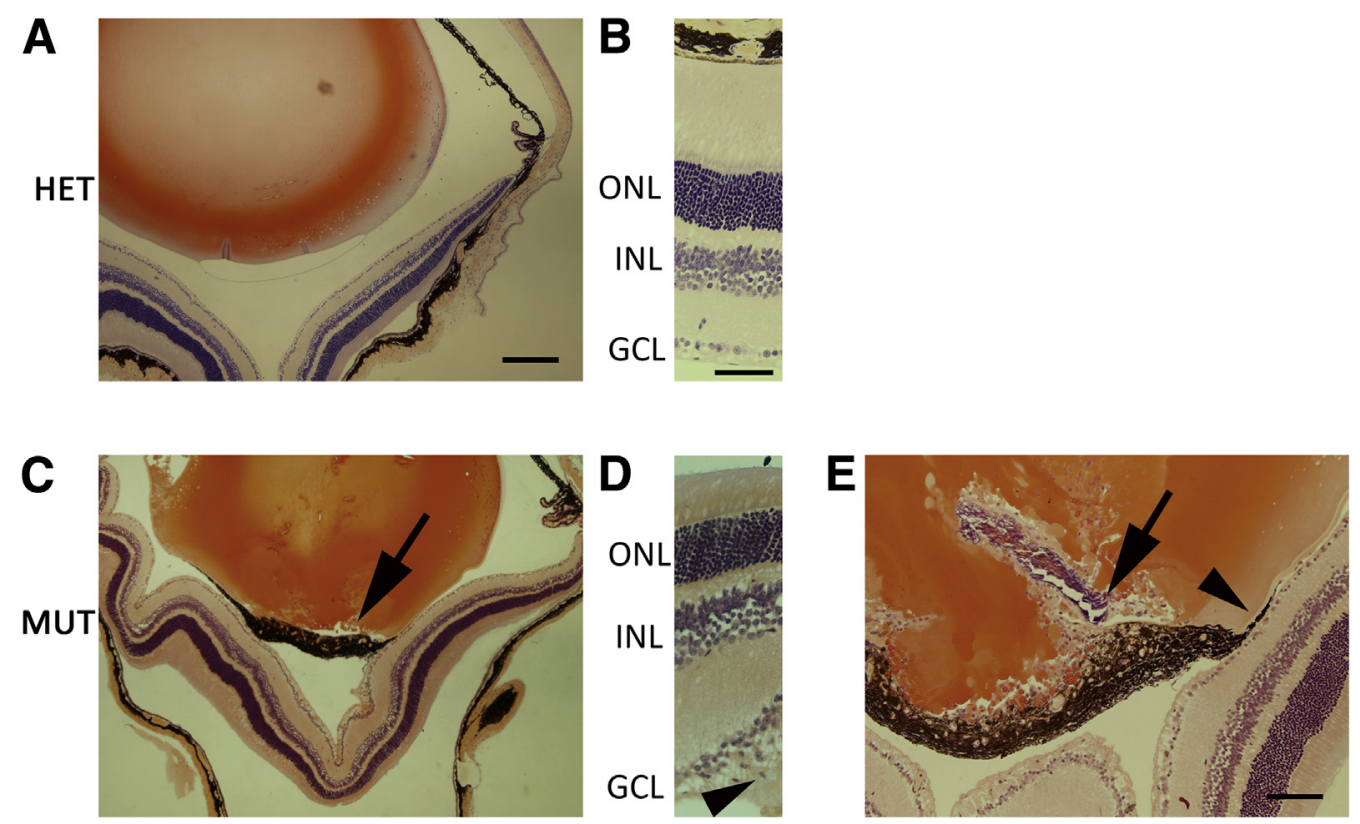

Figure 3 Pathologic features of PHPV phenotype in MUT mice. Photomicrograph of hematoxylin and eosin-stained eyes from HET (A and B) and MUT (C-E) mice. The lens architecture, vitreous space, and retina are normal in the HET eye. The MUT eye is showing misshapen lens (C, arrow). Retinal layers of MUT are normal (D) except some fibro tissue attached to the inner retina (D, arrowhead). The pigmented fibrovascular mass is within the posterior lens (E, arrow), and the membrane attached to the peripheral retina (E, arrowhead). Scale bars: $250 \mu \mathrm{m}(\mathbf{A}$ and $\mathbf{C}) ; 25 \mu \mathrm{m}$ (B and D); $50 \mu \mathrm{m}(\mathbf{E})$. GCL, ganglion cell layer; HET, heterozygous; INL, inner nuclear layer; MUT, mutant; ONL, outer nuclear layer; PHPV, persistent hyperplastic primary vitreous.

measured on OCT images of the whole retinal layer. Inner retinal thickness combined ganglion cell layer, inner plexiform layer, and inner nuclear layer. Both were measured $500 \mu \mathrm{m}$ away from the optic nerve. The total retinal thickness was $211 \pm 5 \mu \mathrm{m}$ for WT and $217 \pm 7 \mu \mathrm{m}$ for HET (Figure 2M), the inner retinal thickness was $89.7 \pm 3.3 \mu \mathrm{m}$ for WT and $89.6 \pm 4.4 \mu \mathrm{m}$ for HET (Figure $2 \mathrm{~N}$ ). No significant difference was found between the WT and HET eyes for total and inner retinal thickness ( $t$-test).

Because decreased central corneal thickness is a risk factor for developing glaucoma in patients with ocular hypertension, ${ }^{70,71}$ we measured the central corneal thickness in all genotypes by OCT (Figure 2O). Central corneal thickness was $116 \pm 16 \mu \mathrm{m}$ for WT, $113 \pm 18 \mu \mathrm{m}$ for HET, and $118 \pm 5 \mu \mathrm{m}$ for MUT eyes (not significant, one-way analysis of variance). There was, however, a difference in the depth of anterior chamber as measured from the posterior of the cornea to the surface of the lens. In the MUT eyes the anterior chamber was $415 \pm 131 \mu \mathrm{m}$, deeper than in WT $(321 \pm 13 \mu \mathrm{m})$ and HET $(294 \pm 53 \mu \mathrm{m})$ eyes $(P<0.05$ versus WT, $P<0.01$ versus HET, one-way analysis of variance) (Figure $2 \mathrm{P}$ ), which may be caused by the abnormal lens. Another risk factor for glaucoma is increased IOP,${ }^{72}$ so we measured the IOP noninvasively in all three groups. The IOPs were $9.71 \pm 1.86 \mathrm{mmHg}$ for WT, $9.48 \pm 1.61 \mathrm{mmHg}$ for HET, and $8.44 \pm 1.07 \mathrm{mmHg}$ for MUT and showed no significant difference between genotypes (one-way analysis of variance) (Figure 2Q).

To correlate clinical findings with pathology, we obtained midline sagittal sections through the eyes of HET and MUT mice. In eyes taken from HET mice, the lens architecture, posterior lens capsule, and vitreous space appeared normal (Figure 3A). As shown in the magnified image (Figure 3B), gross retinal anatomy was also normal. The lens of MUT eyes was misshapen, and the posterior lens capsular was not completely continuous (Figure 3C). Vascular-like structures were visible within the lens, and a pigmented fibro-vascular mass adhered to the posterior lens and the peripheral retina (Figure 3E). However, each layer of the retina was remarkably normal, and there were no overt signs of cell loss or degeneration (Figure 3D).

\section{Ocular Gene Expression Changes in HET and MUT Mice}

To investigate the effects of the 70-kb deletion on the neighboring genes, we extracted total RNA from retina and optic nerve and performed reverse transcription, followed by quantitative PCR, and compared the expression level of surrounding genes between WT, HET, and MUT mice. The relative expression levels were normalized to GAPDH and relative to the expression level of MTAP expression in the WT mice.

Compared with MTAP, the expression level of the ARF gene was extremely low in retina and optic nerve tissue (Figure 4). This suggests that contrary to its role in the developing vitreous, $A R F$ probably does not play a major role in the posterior eye. ${ }^{54}$

In the retinas of HET and MUT mice, the expression of $C D K N 2 B$ was down-regulated (one-way analysis of variance: MUT versus WT, $P<0.01$; HET versus WT, $P<0.01$; HET versus MUT, $P<0.05$ ), but no significant change was found in CDKN2A expression (Figure 4A). Likewise, in the optic nerve tissue in HET and MUT mice, the expression levels of 

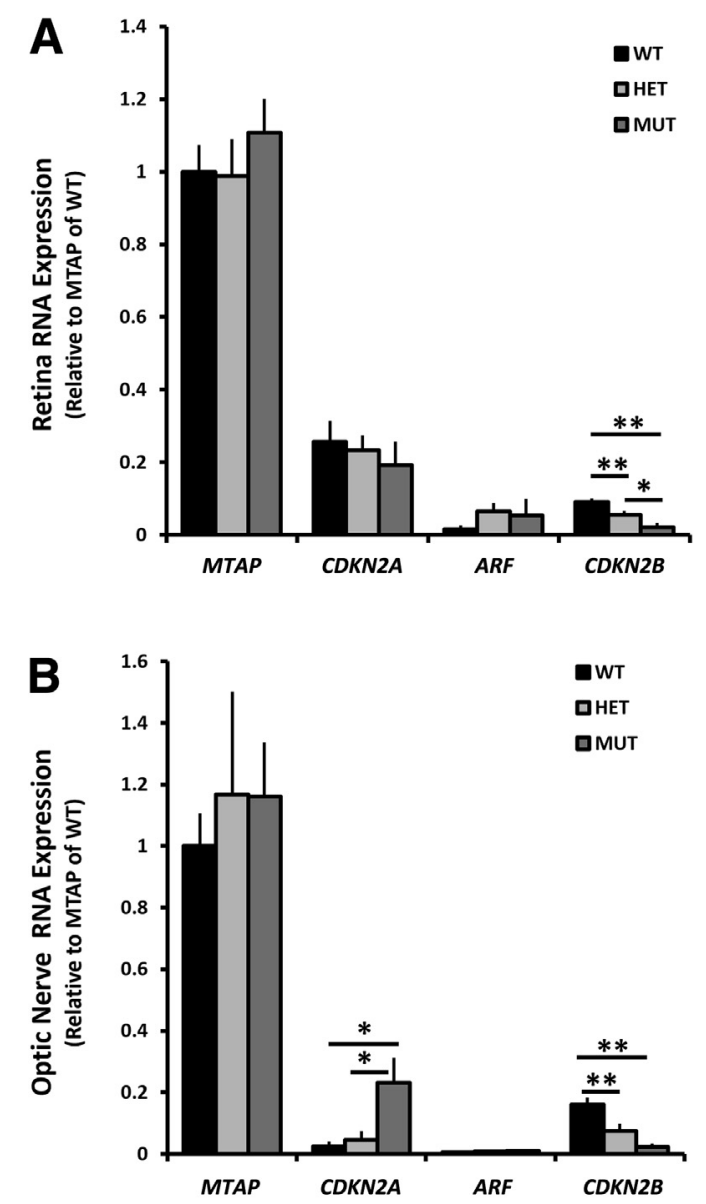

Figure 4 Deletion of the 70-kb interval affects expression of neighboring genes. A: In retina tissue, expression levels of CDKN2B in HET and MUT eyes are significantly reduced. Expression levels of MTAP, CDKN2A, and $A R F$ genes are not significantly altered. B: In optic nerve tissue, expression levels of CDKN2B in HET and MUT eyes are significantly reduced; expression level of CDKN2A in MUT eyes is significantly increased. Expression levels of MTAP and ARF genes are not significantly altered. Data are normalized to $G A P D H$ and relative to the expression level of the MTAP gene in WT eyes. Data are expressed as means \pm SD. $n=5$ eyes per genotype. ${ }^{*} P<0.05,{ }^{*} P<<0.01$ (one-way analysis of variance). HET, heterozygous; MUT, mutant; WT, wild-type.

$C D K N 2 B$ were reduced (one-way analysis of variance: MUT versus WT, $P<0.01$; HET versus WT, $P<0.01$ ). However, $C D K N 2 A$ was up-regulated significantly in MUT mice (oneway analysis of variance: MUT versus WT, $P<0.05$; MUT versus HET, $P<0.05$ ) (Figure 4B). When tested with primers that anneal in exon 3 of $A K 148321$ (proximal to the deletion), the expression of the noncoding RNA is not changed in HET and MUT retinas and optic nerves, agreeing with published results. ${ }^{52}$ In no case was the expression of the MTAP gene changed.

\section{Retinas of the HET and MUT Eyes Are Anatomically Normal}

We next asked whether the partial deletion of $A K 148321$ and the down-regulation of $C D K N 2 B$ in the retina had any subtle effect on retinal anatomy. We stained vertical sections of the retinas of HET and MUT eyes with various cell type-specific antibodies. Antibodies against recoverin labeled the outer nuclear layer (photoreceptors) and cone bipolar cells. Synaptophysin is a marker for the presynaptic elements of conventional and ribbon synapses. It labeled the outer and inner plexiform layers similarly in all genotypes. We also stained for horizontal cells (calbindin), rod bipolar cells $(\mathrm{PKC} \alpha$ ), cholinergic (starburst) amacrine cells (choline acetyltransferease), and ganglion cells ( $\beta$-III-tubulin). In no case did we observe changes in the numbers or the morphology of these cell types (Figure 5, A-E, G-K, $\mathrm{M}-\mathrm{Q}$ ).

Because $C D K N 2 B-A S$ and $C D K N 2 B$ may be involved in the ganglion cell response to elevated IOP, we wanted to test whether the numbers of ganglion cells are reduced in HET and MUT mice compared with the WT mice. We double-labeled ganglion cells in retinal whole mounts with antibodies against $\beta$-III-tubulin and the transcription factor Brn3a. Ganglion cells were counted in WT, HET, and MUT eyes ( $n=7$ eyes for each genotype). The ganglion cell densities of WT, HET, and MUT eyes were similar $\left(4569 \pm 397 / \mathrm{mm}^{2}, 4468 \pm 122 / \mathrm{mm}^{2}\right.$, and $4512 \pm 339 / \mathrm{mm}^{2}$, respectively; no significant difference by one-way analysis of variance) (Figure 5, F, L, R, and S).

Because the 9p21 region also associated with cardiovascular disease, ${ }^{73,74}$ and because vascular smooth muscle cells from the MUT strain exhibit increased proliferation in tissue culture, ${ }^{51}$ we stained the retinal whole mounts with the use of an antibody against endomucin, which stains venous endothelium and capillaries, ${ }^{75}$ and isolectin IB4, which stains all blood vessels, including arteries. ${ }^{76}$ Blood vessels in WT, HET, and MUT retina appeared normal (Supplemental Figure S1).

\section{Retinal Function of $\Delta 4 C 4-C 5$ Mice}

The visual acuity of mice was estimated by optomotor reflex-based spatial frequency threshold test. The mean visual acuity of WT ( $n=14$ eyes) and HET ( $n=12$ eyes) mice was normal, with $0.36 \pm 0.04$ and $0.32 \pm 0.05$ cycle/ degree, respectively. The MUT ( $n=10$ eyes) eyes had poorer visual acuity $(0.11 \pm 0.1$ cycle/degree; $P<0.01$ versus WT and HET, one-way analysis of variance) (Figure 6A). A large variation was found in the visual acuity in the MUT mice because five MUT eyes had poor acuity $(<0.05$ cycle/degree), whereas one MUT eye was almost normal ( 0.3 cycle/degree).

The finding that some MUT mice had almost normal acuity suggests that the visual acuity in this genotype is limited by the variation in lens opacity rather than a functional deficit of the retina itself. We therefore performed scotopic threshold ERG, scotopic ERG, and photopic ERG to investigate retinal and inner retinal function. The STR recently was shown to be directly dependent on intact retinal ganglion cell function. ${ }^{66,77-80}$ The STR contains a positive component, followed by a negative component, designated as the pSTR and nSTR, 

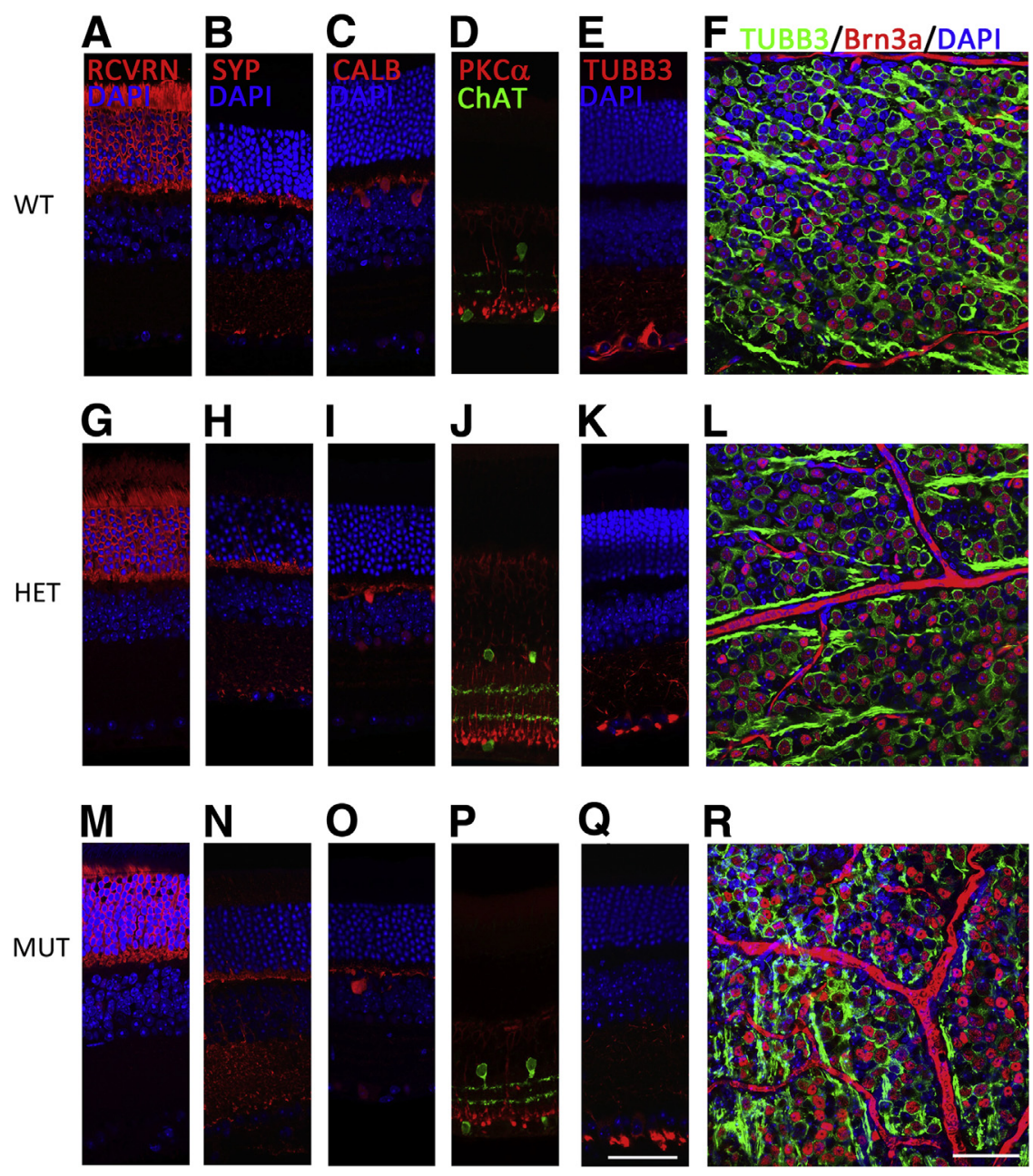

S

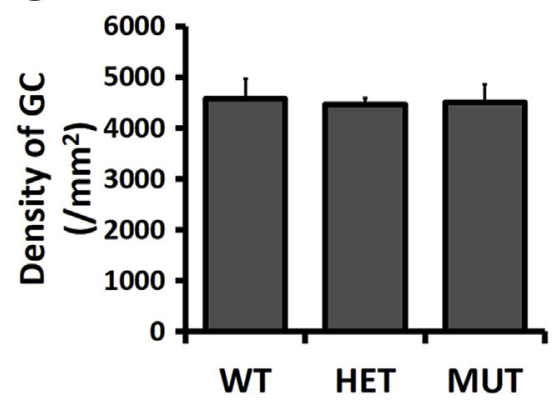

Figure 5 The retinas of the HET and MUT eyes are anatomically normal. A-F: WT; G-L: HET; M-R: MUT. DAPI applied as nuclear dye. A, G, and M: Rabbit anti-Recoverin antibody labels retinal outer nuclear layer. B, H, and N: Rabbit anti-synaptophysin antibody labels retinal outer plexiform layer. C, I, and 0: Rabbit anti-calbindin antibody labels horizontal cells. D, J, and P: Rabbit anti-PKC $\alpha$ antibody labels rod bipolar cells, goat anti-ChAT antibody labels cholinergic amacrine cells. E, K, and Q: Rabbit anti- $\beta$-III-tubulin antibody labels ganglion cells. F, L, and R: Images are representative of three eyes per genotype. Rabbit anti- $\beta$-III-tubulin antibody and mouse anti-Brn3a antibody was used to double label ganglion cells on the retinal flat mount. All of the above cells in HET and MUT retina have a normal cell morphology and distribution pattern. Images presented were single focal plane scans. S: The ganglion cell densities are normal and have no obvious difference among each genotype (one-way analysis of variance). Eight mid-periphery regions per retina were counted manually. Data are expressed as means \pm SD. $n=3$ eyes per genotype $(\mathbf{F}, \mathbf{L}$, and $\mathbf{R})$; $n=7$ eyes per genotype (S). CALB, Calbindin; ChAT, choline acetyltransferease; GC, ganglion cell; GS, glutamine synthetase; HET, heterozygous; Mut, mutant; RCVRN, Recoverin; SYP, Synaptophysin; TUBB3, $\beta$-III-tubulin; WT, wildtype. Scale bar $=50 \mu \mathrm{m}$. respectively. For scotopic response analysis, the a-wave amplitude was measured from baseline to the trough of the first negative wave, and the b-wave amplitude was measured from the trough of the a-wave to the peak of the positive wave. For photopic response analysis, the b-wave amplitude was measured from the trough of the a-wave to the peak of the positive wave. The amplitudes of each wave are shown in Figure 6, B-E. In most cases the amplitudes of WT and HET eyes were similar and overlapped; however the amplitude of MUT eyes was lower. With the increase of the stimulus intensity, the difference of amplitudes between MUT eyes and the other two groups was larger. We used one-way analysis of variance to test the differences of amplitudes at each stimulus intensity; for the pSTR wave, the differences were significant at the intensities larger than $-4.5 \log \mathrm{cd} . \mathrm{s} / \mathrm{m}^{2}$; for scotopic a-wave, the differences were significant at intensities larger than $-2.4 \log \mathrm{cd} . \mathrm{s} / \mathrm{m}^{2}(P<0.05)$; for scotopic b-wave, the differences were significant at every stimulus intensity $(P<0.05)$; for photopic b-wave, the differences were significant at intensities larger than 0.8 $\log \mathrm{cd} . \mathrm{s} / \mathrm{m}^{2}(P<0.05)$. The lower amplitude of MUT may result because the actual stimulus intensities were smaller due to the lens and the retrolental tissue. 
A

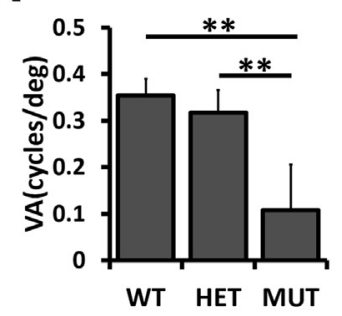

B

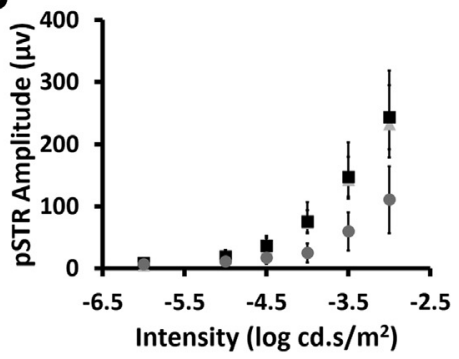

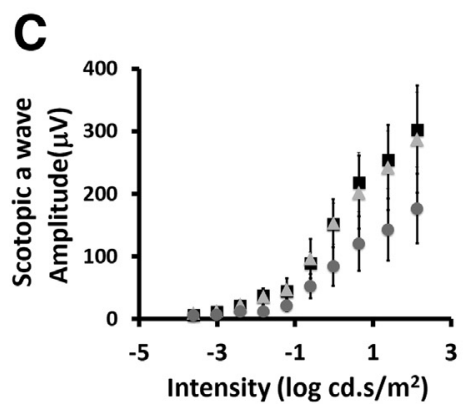
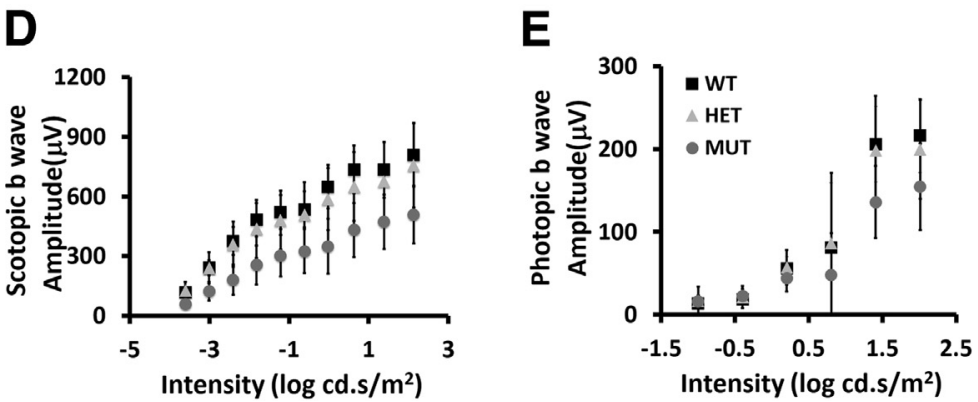

Figure 6 Visual function features of the PHPV phenotype in MUT mice. A: Visual acuity assessed by OKR shows that the WT and HET mice have normal visual acuity and that MUT mice have much poorer visual acuity. B-E: Serial ERG amplitude versus stimulus intensity after dark and light adaptation. B: pSTR. C: Scotopic a-wave. D: Scotopic b-wave. E: Photopic b-wave. Amplitudes of each wave in WT and HET eyes are similar, whereas the MUT eyes have lower amplitudes. Data are expressed as means \pm SD. $n=14$ eyes in WT, 12 eyes in HET, 10 eyes in MUT. ** $P<0.01$ (one-way analysis of variance). ERG, electroretinography; HET, heterozygous; MUT, mutant; PHPV, persistent hyperplastic primary vitreous; OKR, optokinetic reflex; pSTR, positive scotopic threshold response; VA, visual acuity; WT, wild-type.

\section{Glial Cells Are Activated in the Retina and Optic Nerve Head of MUT Eyes}

Activation of astrocytes in the optic nerve head was described in glaucoma. ${ }^{56,81}$ Therefore, we also looked into the glial cells in retina and optic nerve head area of three groups of mice.

GS is a Müller cell marker in the retina. ${ }^{82}$ In normal retinas, Müller cell fibers traverse the whole retinal thickness, and GS immunoreactivity is strongest within the cell soma (Figure 7A). The GS expression in HET retina looked similar to the WT retina (Figure 7D). In MUT retina, there was an increase in GS immnunoreactivtiy in Müller glia endfeet, adjacent to ganglion cells (Figure 7G). In the WT retina, GFAP is localized to the Müller glia endfeet and astrocytes in the optic fiber layer (Figure 7B). The GFAP expression in HET retina appeared normal (Figure 7E). In MUT retinas, there was an increase in GFAP immunoreactivity in the optic fiber layer and in occasional thin processes of glia that spanned the inner plexiform layer (Figure $7 \mathrm{H}$ ).

Iba1 immunoreactivity was used to examine the morphology and distribution of microglia in the retina. ${ }^{83} \mathrm{In}$ the retina of WT and HET eyes, Ibal stained ramified microglia in the inner and outer plexiform layers (Figure 7, $\mathrm{B}$ and $\mathrm{E})$. In the MUT retina, Iba $1^{+}$microglia showed more rounded cell morphology and thickened processes, features that are associated with microglial activation (Figure $7 \mathrm{H}$ ). Cell densities of microglia were counted in the outer plexiform layer (mid-peripheral area) in WT ( $n=7$ eyes), HET
( $n=8$ eyes), and MUT ( $n=6$ eyes) eyes. Our results of WT and HET $\left(128.1 \pm 7.6 / \mathrm{mm}^{2}, 136.4 \pm 6.7 / \mathrm{mm}^{2}\right.$, respectively) were in agreement with a previous study. ${ }^{84}$ The microglia densities of MUT eyes $\left(181.9 \pm 41.3 / \mathrm{mm}^{2}\right)$ were higher than WT and HET (one-way analysis of variance, $P<0.01$ ) (Figure $7, \mathrm{C}, \mathrm{F}, \mathrm{I}$, and $\mathrm{J}$ ).

In the optic nerve head, $\mathrm{GFAP}^{+}$astrocytes form the glial lamina and ensheath the unmyelinated axon bundles. ${ }^{64}$ The GFAP expression in transverse optic nerve head sections of all three genotypes was normal (Figure 8, A, D, and G). In WT and HET mice, the $\mathrm{Iba}^{+}$cells of the nerve head showed the ramified morphology of surveilling microglia (Figure 8, B and E). ${ }^{85}$ The Ibal-expressing microglia in optic nerve heads from MUT mice appeared to show a more rounded morphology and retraction of fine processes that is consistent with microglial activation (Figure $8 \mathrm{H}$ ). We therefore took high-power image stacks through individual $\mathrm{Iba}^{+}$cells to show the morphology of individual microglial cells (Figure 8, C, F, and I).

\section{Induction of Elevated IOP by Microbead Injection into the Anterior Chamber}

We used the microbead occlusion model to induce a glaucomatous injury in mice of all three genotypes. ${ }^{61,62}$ Eleven WT, 12 HET, and 9 MUT mice were injected unilaterally (Supplemental Figure S2A). In one WT mouse, the IOP failed to increase, and one HET mouse developed an infection in the anterior chamber. These mice were removed from the study. In addition, a cohort of 11 mice was injected 


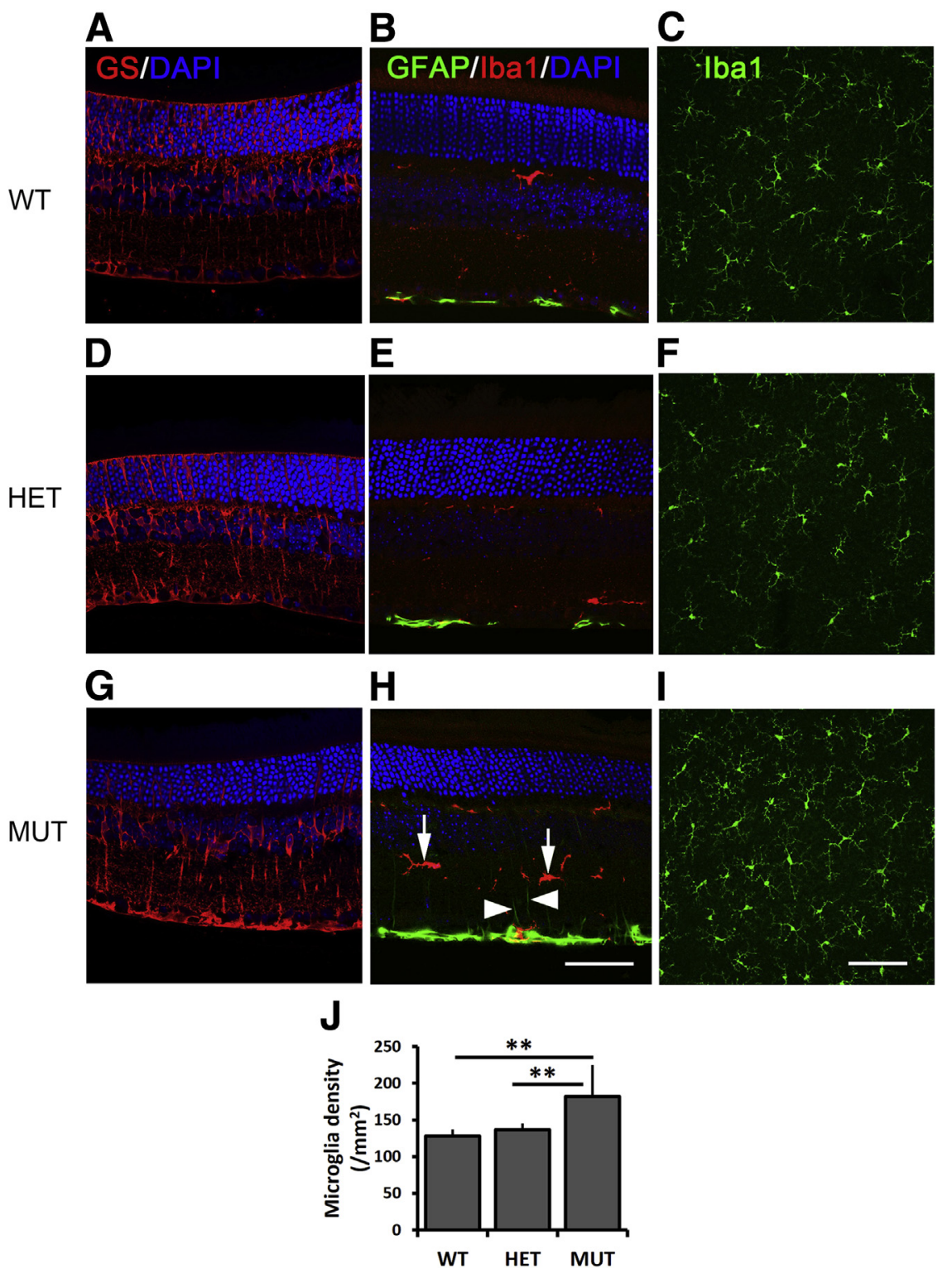

Figure 7 Glial cells are activated in the retina of MUT eyes. A-C: WT; D-F: HET; G-I: MUT. A, D, and G: Rabbit anti-GS antibody labels Müller glia in the retina. B, E, and H: Chicken anti-GFAP antibody labels astrocytes and Müller glia, rabbit anti-Iba1 labels microglia in retina. C, F, and I: Rabbit anti-Iba1 labels microglia in retinal whole mounts (outer plexiform layer). The glia cells are normal in retinas of WT and HET eyes. $\mathbf{G}$ and $\mathbf{H}$ : In MUT retina, there is an increased GS intensity in Müller glia endfeet (G), increased GFAP immunoreactivity in the optic fiber layer $(\mathbf{H})$, and in occasional thin processes of glia spanning the inner plexiform layer ( $\mathbf{H}$, arrowheads). The microglia labeled with Iba1 appears to be more rounded in cell morphology and has thickened processes $(\mathbf{H}$, arrows). C, F, and I: Microglia in the outer plexiform layer in MUT retina shows smaller size but increased numbers. J: The microglia cell density of MUT is higher than WT and HET in the outer plexiform layer. Four mid-periphery regions per retina were counted manually in Image J. Data are expressed as means \pm SD. $n=7$ eyes in WT, 8 eyes in HET, 6 eyes in MUT. ${ }^{*} P<0.01$, one-way analysis of variance. Images are representatives of single focal plane scans (A, B, D, E, G, and $\mathbf{H})$ and of collapsed confocal image stacks (C, F, and I) (50 image planes, taken at $0.5-\mu \mathrm{m}$ z-step size). GFAP, glial fibrillary acidic protein; GS, glutamine synthetase; HET, heterozygous; Iba1, ionized calcium-binding adaptor molecule 1; MUT, mutant; WT, wild-type. Scale bars: $50 \mu \mathrm{m}$ (A, B, D, E, G, and $\mathbf{H}) ; 100 \mu \mathrm{m}$ (C, F, and $\mathbf{I})$.

with sterile saline solution as a control to exclude the possibility that any manipulation of the eye may cause an increase in pressure or ganglion cell loss. In no case did saline injection lead to an increase in IOP or ganglion cell loss (Supplemental Figure S2B).

The microbead occlusion model of IOP elevation in rodents has, since its inception, gained wide acceptance. ${ }^{61,69,86,87}$ However, a noted problem is that the IOP increase is relatively variable in amount and duration between individual animals in a cohort. It has therefore been suggested to use the cIOP (defined as the area under the curve of IOP over time, measured in mmHgDays) as an estimate of the total pressure insult to which the eye was subjected. ${ }^{69}$ The $\Delta$ cIOP (cIOP in the experimental eye minus cIOP in the control eye) was $210.5 \pm 89.1 \mathrm{mmHgDays}(n=10$, means $\pm \mathrm{SD})$ for the WT, $236.9 \pm 87.4 \mathrm{mmHgDays}(n=11)$ for the HET, and $232.1 \pm 77.2 \mathrm{mmHgDays}(n=9)$ for the MUT (not significant, analysis of variance). We were concerned that an excessively high IOP, even if sustained only for a few days, may cause more damage than would be predicted from the cIOP alone, so we compared the maximum IOPs that were measured during the experimental period in individual eyes for each strain. Maximum IOP for the WT was 25.4 $\mathrm{mmHg}$ (range, 19.8-29.6 $\mathrm{mmHg}$ ), for the HET was 26.1 $\mathrm{mmHg}$ (range, 20-30.8 $\mathrm{mmHg}$ ), and for the MUT was $23.8 \mathrm{mmHg}$ (range, 20.6-37.4 $\mathrm{mmHg}$ ). The differences in mIOP between strains were not significant (analysis of variance). Taken together, this indicates that the animals of all three genotypes received comparable pressure insults (Figure 9, A and B).

\section{Ganglion Cell Loss and Axon Degeneration after IOP Elevation}

We determined retinal ganglion cell loss by counting wholemounted retinas after staining for Brn3a (Figure 10, A-F). 

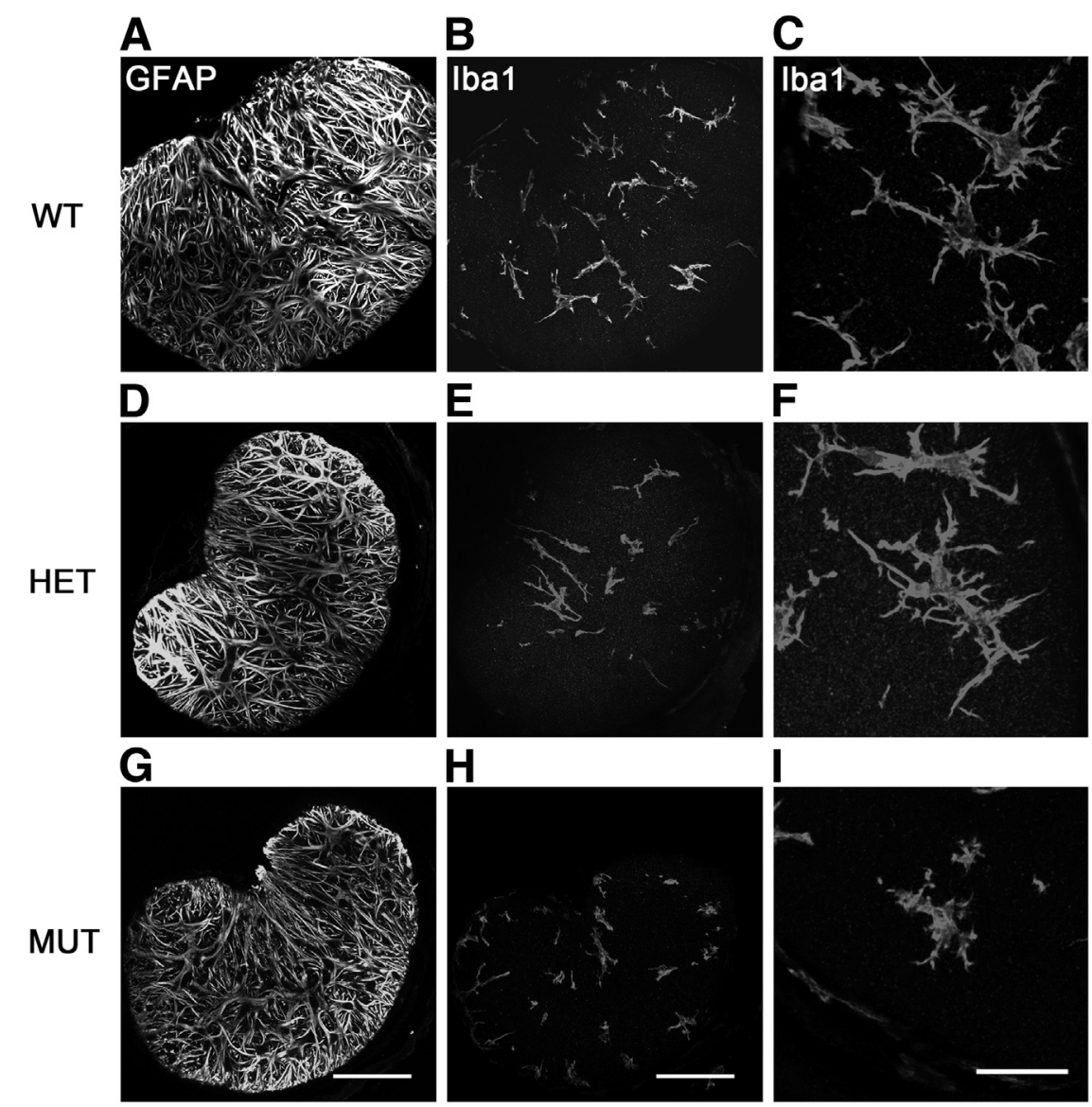
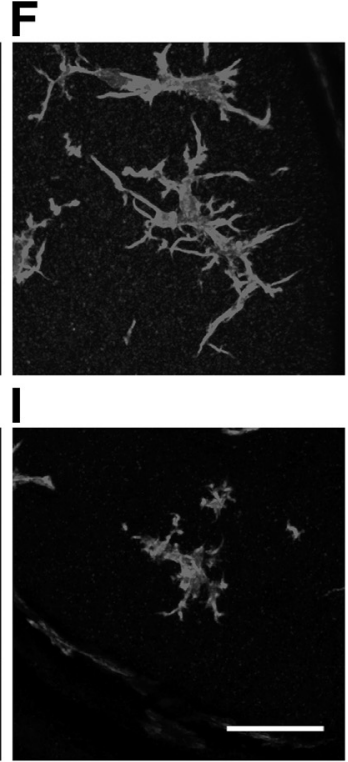

Figure 8 Microglial cells are activated in the optic nerve head of MUT eyes. A-C: WT; D-F: HET; G-I: MUT. A, D, and G: GFAP labeling of astrocytes in the optic nerve head shows no differences between genotypes. Single confocal image planes through the optic nerve head are shown. B, E, and H: Rabbit anti-Iba1 stains microglia in the optic nerve head. The images are representative of collapsed confocal image stacks (50 image planes, taken at $0.4 \mu \mathrm{m}$ z-step size) to show the whole cell morphology. Microglia in MUT mice appear more rounded and have fewer fine processes $(\mathbf{H}) . \mathbf{C}, \mathbf{F}$, and I: High-power views of individual microglial cells stained for Iba1. The images represent collapsed confocal stacks (50 image planes, taken at $0.4-\mu \mathrm{m}$ z-step size). GFAP, glial fibrillary acidic protein; HET, heterozygous; Iba1, ionized calciumbinding adaptor molecule 1; MUT, mutant; WT, wild-type. Scale bars: $50 \mu \mathrm{m}$ (A, B, D, E, G, and H); $20 \mu \mathrm{m}(\mathbf{C}, \mathbf{F}$, and I).
It was reported recently that an increase in IOP in one eye also affects the contralateral eye to some extent, and especially that it causes activation of macroglial and microglial cells in the contralateral eye. ${ }^{88,89}$ Because we observed an increase in microglial cell counts and activation in MUT mice even in the absence of IOP elevation, we first determined whether we could detect ganglion cell loss in the contralateral eyes compared with naive controls for all three genotypes (Figure 9C). In WT mice, the ganglion cell counts in the contralateral eyes were $4412 \pm 191 \mathrm{cells} / \mathrm{mm}^{2}$ (versus 4569 cells $/ \mathrm{mm}^{2}$ in naive eyes; not significant), and in HET eyes they were $4547 \pm 294$ cells $/ \mathrm{mm}^{2}$ (versus 4468 cells $/ \mathrm{mm}^{2}$ in naive eyes; not significant). However, the contralateral MUT eyes showed a loss of ganglion cells with $3945 \pm 375$ cells $/ \mathrm{mm}^{2}$ [versus 4512 cells $/ \mathrm{mm}^{2}$ in naive eyes, corresponding to a $12.57 \%$ cell loss $(P<0.01, t$-test $)]$. We therefore calculated all ganglion cell losses in the injected eyes relative to naive eyes of the same genotype.

Although the mean ganglion cell loss in the microbeadinjected eyes was similar in WT and HET mice $(22.4 \% \pm 6.5 \%$ in RGC loss in WT and $20.1 \% \pm 7.2 \%$ in HET; not significantly different), the MUT eyes lost $35.8 \% \pm 7.1 \%$ of their ganglion cells. This difference was significant $(P<0.001$, one-way analysis of variance) (Figure 9D). We then correlated the $\Delta$ cIOP for the $10 \mathrm{WT}$ mice with the ganglion cell loss in the retina to test how well $\Delta$ cIOP would predict ganglion cell loss (Figure 9E). In agreement with earlier studies, ${ }^{69}$ we found $\Delta$ cIOP to correlate with ganglion cell loss $\left(R^{2}=0.5324\right)$. HET mice followed the same trend as the WT mice, but MUT mice showed a larger ganglion cell loss than would be predicted from the pressure insult they sustained (Figure $9 \mathrm{E}$ and Figure 10, A-F).

We also evaluated the degree of the axon degeneration induced by IOP elevation by staining optic nerve crosssections with PPD (Figure 10, G-I) and grading them on a scale from 1 to $5 .^{68}$ Optic nerves from saline-injected eyes had a mean score of $1.45 \pm 0.37(1.3 \pm 0.24$ in the contralateral eyes; not significant). Optic nerve grades were worse in injected eyes compared with the contralateral eyes $(1.85 \pm 0.63$ versus $1.35 \pm 0.39$ for $\mathrm{WT}, 1.86 \pm 0.74$ versus $1.22 \pm 0.33$ for HET; $P<0.05, t$-test). As expected from the observation that the MUT mice lose ganglion cells in the uninjected eyes, contralateral MUT optic nerves had a mean nerve score of $1.94 \pm 0.86$. In the microbead-injected eyes the nerve score showed a tendency to further increase to $2.22 \pm 0.85$, although this difference was not significant (Supplemental Figure S3).

\section{Microglial Activation after IOP Elevation}

As described in Glial Cells Are Activated in the Retina and Optic Nerve Head of MUT Eyes, the microglia in MUT optic nerve heads were activated with less ramified 
A

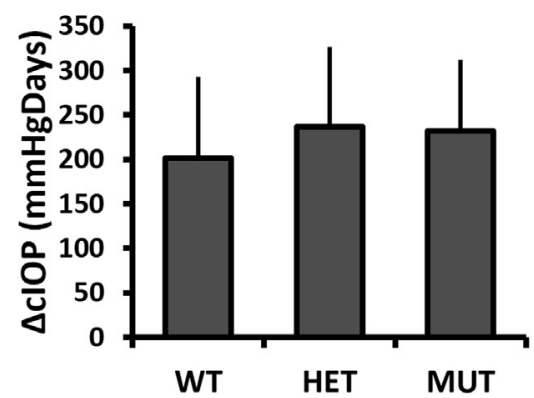

C

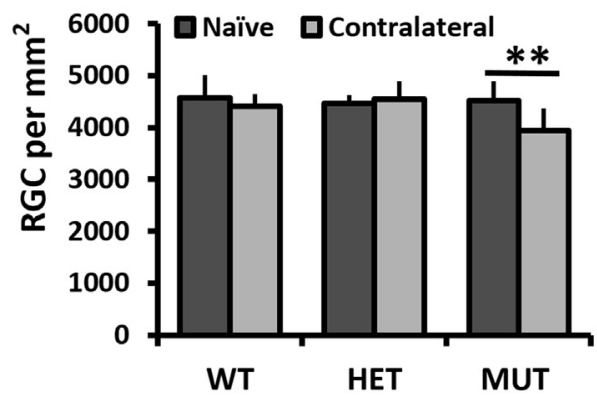

$\mathbf{E}$

\section{B}

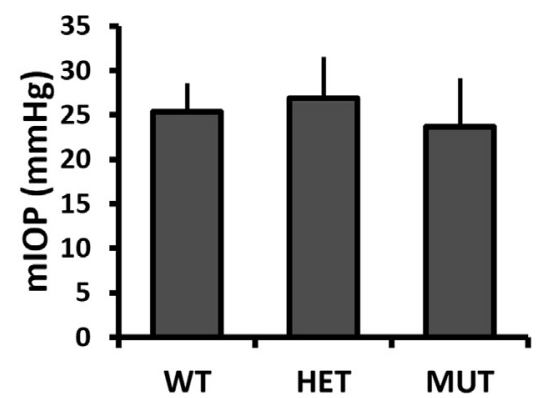

D
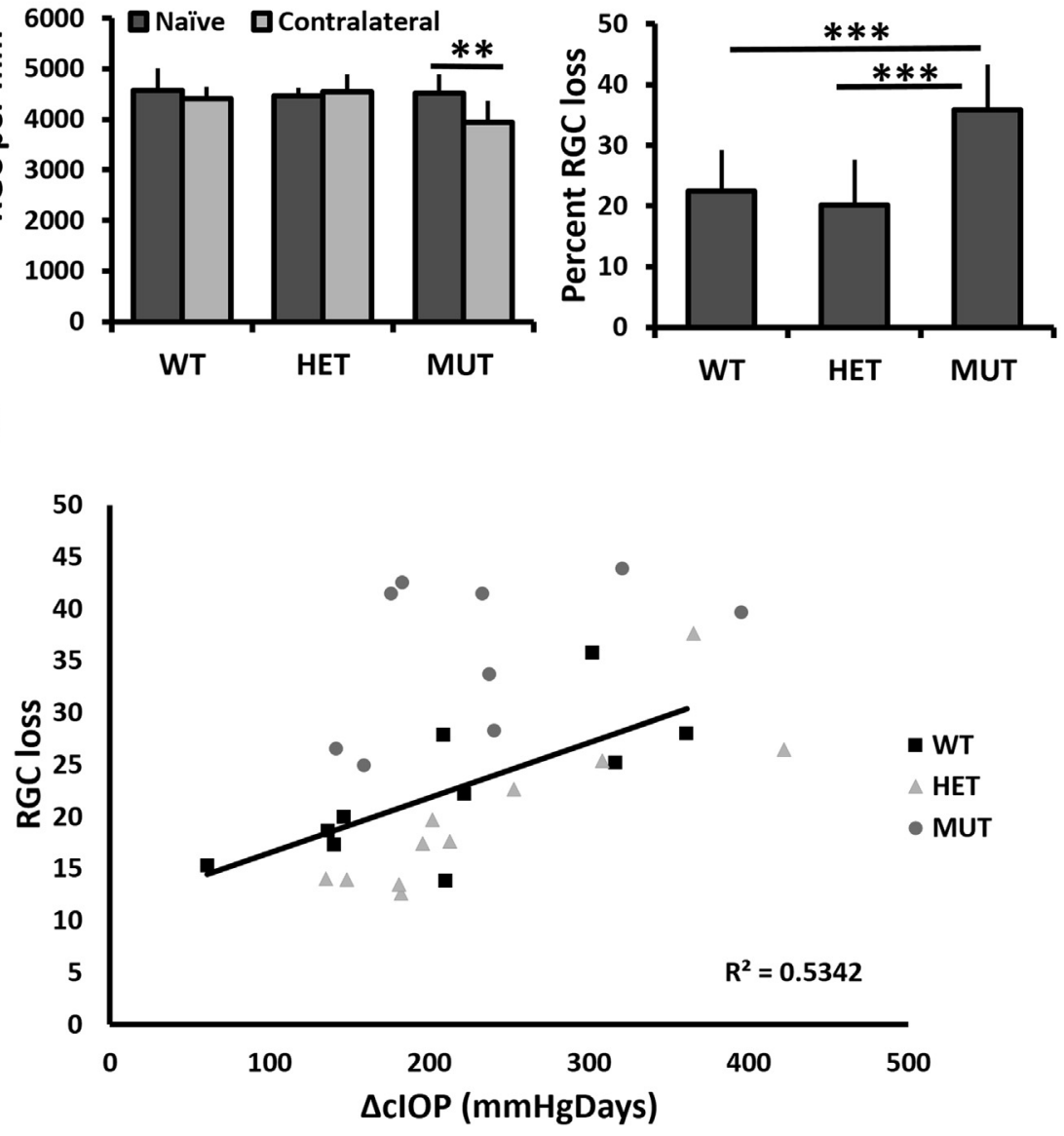

Figure 9 IOP and retinal ganglion cell loss after microbead injection. A: $\Delta$ cIOPs was similar for mice from WT, HET, and MUT groups. B: mIOPs were similar in WT, HET, and MUT groups. C: Ganglion cell loss in the contralateral (noninjected) eye was determined by comparing Brn3alabeled cells in the contralateral eye with naive controls. In WT and HET, no significant difference was found, but in the MUT the contralateral eye shows a loss of ganglion cells. D: Ganglion cell loss in the microbead-injected eyes compared with naive eyes in WT, HET, and MUT. MUT has a greater loss than WT and HET. E: $\triangle$ CIOP correlates with ganglion cell loss in WT and HET $\left(R^{2}=0.5342\right.$ in WT), but MUT eyes are affected more severely than would be predicted from their $\Delta$ cIOP. Data are expressed as means \pm SD. $n=10 \mathrm{WT}, n=11$ HET, and $n=9$ MUT. ${ }^{* *} P<0.01$ (t-test), $* * * P<0.001$ (one-way analysis of variance). HET, heterozygous; IOP, intraocular pressure; mIOP, maximum IOP that was recorded during the experimental period; MUT, mutant; RGC, retinal ganglion cell; WT, wild-type; $\Delta$ cIOP, difference of cumulative IOP in the experimental and the control eyes. appearance even under normal IOP. Because the severity of glaucomatous neurodegeneration can be predicted from the microglia alterations, ${ }^{90}$ we next observed the morphology of microglia by staining cross-sections of optic nerve heads with Iba1 1 month after IOP elevation. The microglia of all three genotypes showed signs of activation; however, the degree of morphologic changes were different (Figure 10, M-O). Compared with WT and HET mice, the microglia in MUT mice have a more rounded morphology, with thicker and shorter processes. The grade of microglia activation had the same trend as ganglion cell loss and axonal degeneration.

\section{Ganglion Cell Function Loss after IOP Elevation}

One month after microbead injection, consistent with the greater loss of ganglion cells, MUT mice also showed greater visual function loss (Figure 11). Figure 11, A, B, and D, shows examples of individual waveforms from WT and MUT eyes. Amplitude loss percentage for individual mice was calculated as the reduction (baseline amplitude before injection minus amplitude after microbead injection) compared with its own baseline. The amplitude loss percentage in the pSTR ERG, which reflects ganglion cell function, was significantly greater $(n=5$ eyes for each 


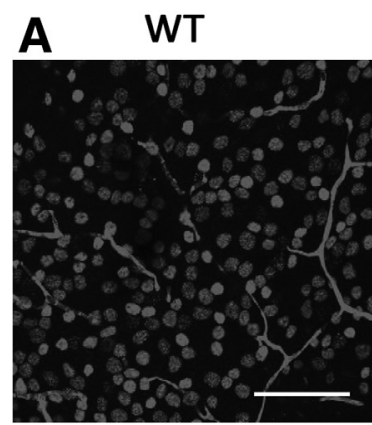

D

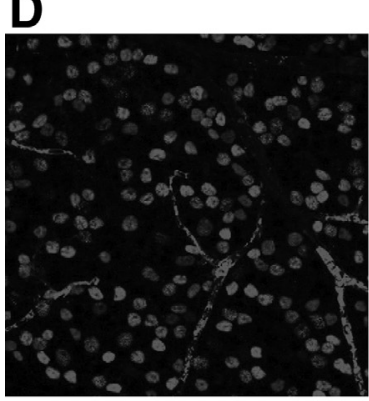

G

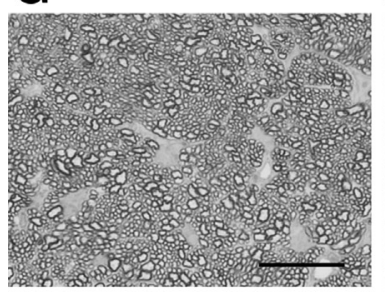

$\mathbf{J}$

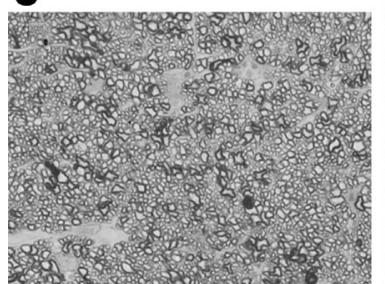

M

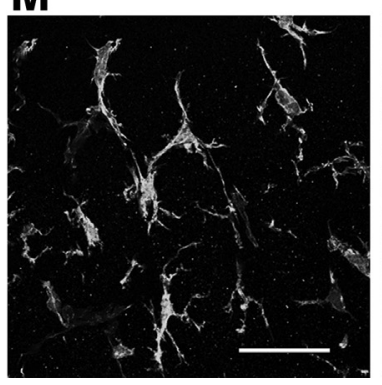

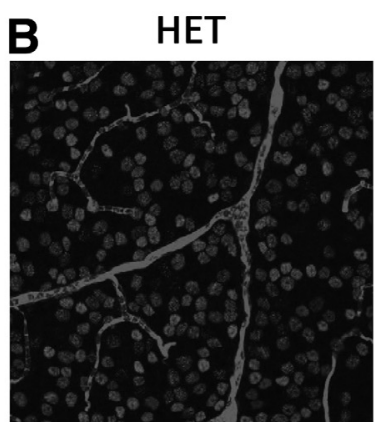

E

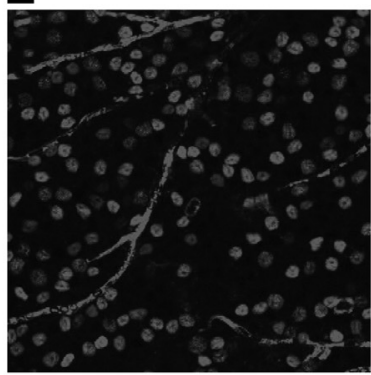

H
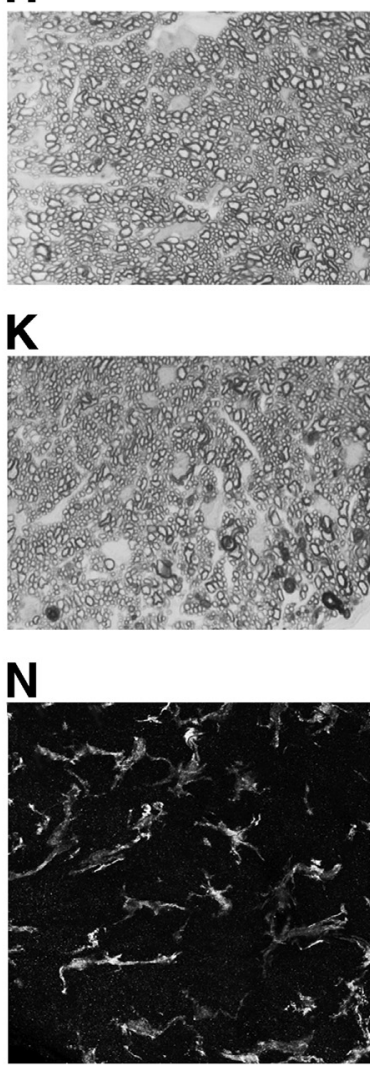

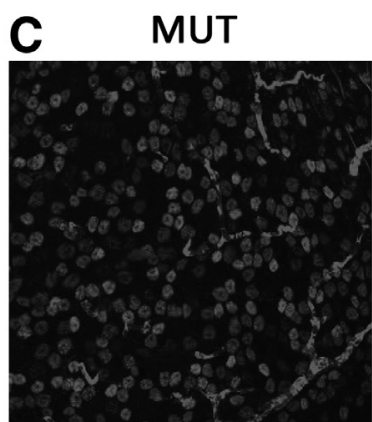

$\mathbf{F}$

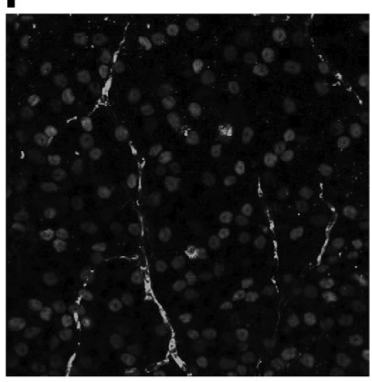

\section{I}
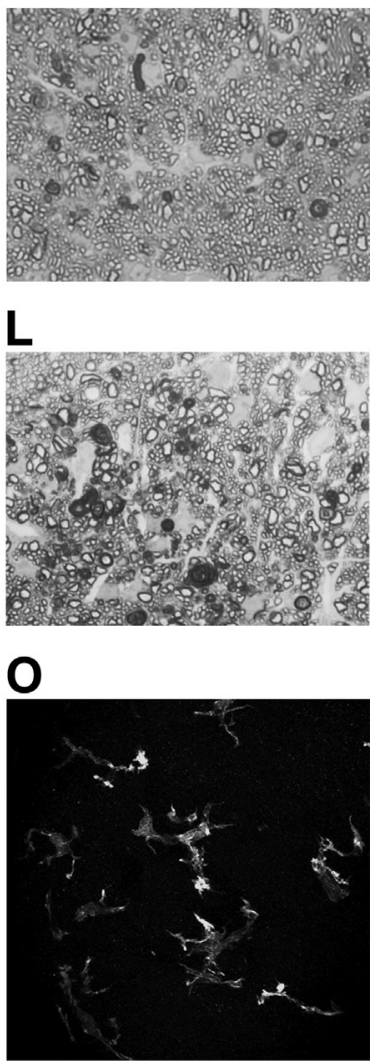

Figure 10 Ganglion cell loss, axon degeneration, and microglia activation after microbead injection. A, D, G, J, and $\mathbf{M : ~ W T ; ~ B , ~ E , ~ H , ~ K , ~ a n d ~} \mathbf{N}$ : HET; C, F, I, L, and 0: MUT. A-C: Mouse antiBrn3a labeling of ganglion cells in retina of contralateral eyes. D-F: Brn3a labeling of ganglion cells in retina of microbead-injected eyes. Ganglion cell loss is more obvious in MUT eyes. The images are collapsed confocal image stacks (15 image plane, taken at $0.5 \mu \mathrm{m}$ z-step size) in midperiphery regions of retinal whole mounts. G-I: PPD staining of optic nerve axons of contralateral eyes. J-L: PPD staining of optic nerve axons of microbead-injected eyes. There are several focally degenerating axons present in WT and HET, and more degenerating axons with disorganized connective tissue in MUT, the contralateral MUT optic nerve also show focally degenerating axons. $\mathbf{M}-\mathbf{0}$ : Rabbit anti-Iba1 stains microglia in the optic nerve head of microbead-injected eyes. The images are collapsed confocal image stacks (50 images planes, taken at $0.4-\mu \mathrm{m}$ z-step size) to show the individual microglial cells. Microglia of the three genotypes all appear more rounded and have fewer fine processes compared with their naive eyes (Figure 8, C, F, and I). Microglia in MUT shows more reactivity than WT and HET. All images are representatives of three genotypes. HET, heterozygous; MUT, mutant; PPD, paraphenylene diamine; WT, wild-type. Scale bars: $50 \mu \mathrm{m}(\mathbf{A}-\mathbf{F})$; $20 \mu \mathrm{m}(\mathbf{G}-\mathbf{L}) ; 30 \mu \mathrm{m}(\mathbf{M}-\mathbf{0})$. genotype; $P<0.01$, one-way analysis of variance) in MUT mice than in WT mice at the stimulus intensity of $-4.5 \mathrm{log}$ cd.s $/ \mathrm{m}^{2}(59.5 \% \pm 14.3 \%$ in WT, $70.3 \% \pm 7.7 \%$ in HET, $76.7 \% \pm 12.2 \%$ in MUT), $-4 \log \mathrm{cd} . \mathrm{s} / \mathrm{m}^{2}(58.7 \pm 13.6 \%$ in WT, $72.1 \pm 10.2 \%$ in HET, $84.2 \pm 4.9 \%$ in MUT), and -3.5 $\log \mathrm{cd} . \mathrm{s} / \mathrm{m}^{2}(55.5 \% \pm 11.8 \%$ in WT, $70.2 \% \pm 5.5 \%$ in HET, $80.7 \% \pm 16.0 \%$ in MUT) (Figure 11C), whereas the loss in HET mice was between that in WT and MUT mice, which was not significant.

\section{Gene Expression Changes after IOP Elevation}

Because $C D K N 2 B$ is implicated in the $T G F B$ signaling pathway, ${ }^{28,29}$ and changes in $T G F B$ signaling were described 
A

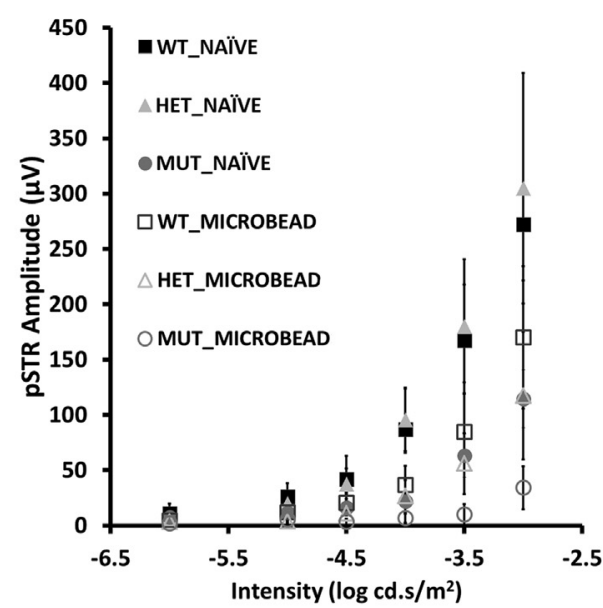

C

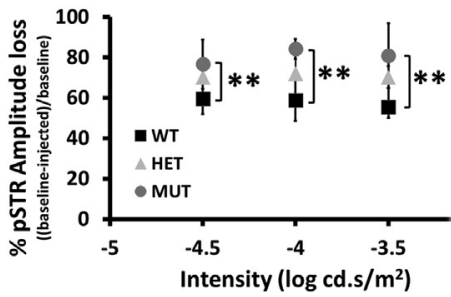

B
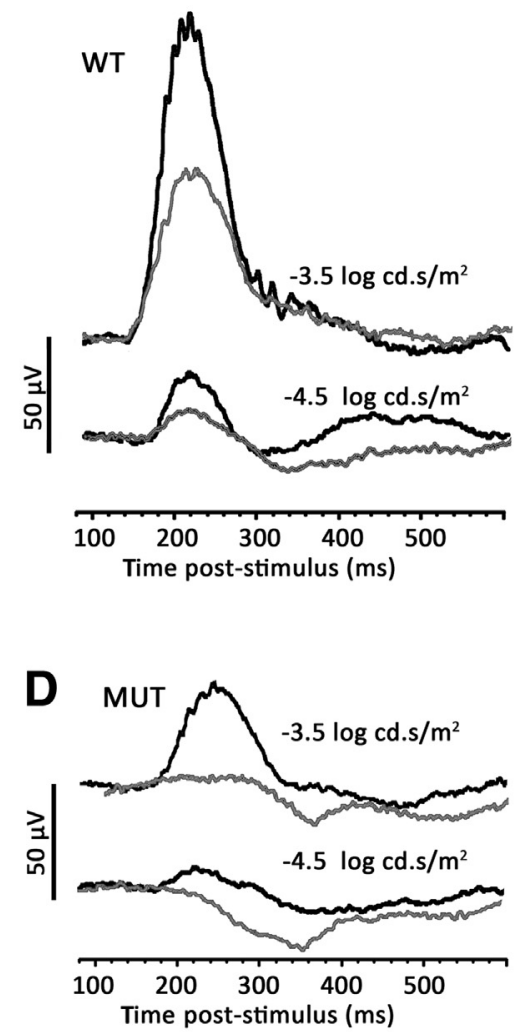

Figure 11 PSTR ERG wave form and amplitude loss after microbead injection. A: Serial PSTR ERG amplitude versus stimulus intensity in naive and microbead-injected eyes of three genotypes. MUT mice show a greater reduction in amplitude at all stimulus intensities. C: Statistical comparison of pSTR amplitude loss at the stimulus intensity of $-4.5,-4$, and $-3.5 \log \mathrm{cd} . \mathrm{s} / \mathrm{m}^{2}$. A significant difference was found in PSTR amplitudes between WT and MUT. B and D: Representative individual waveforms of PSTR ERG in naive eyes (black traces) and microbead-injected (gray traces) eyes from WT (B) and MUT (D) mice. Stimulus flash intensities are listed above the wave forms. Poststimulus time line is listed below waveforms. Data are expressed as means \pm SD. $n=5$ eyes per genotype. ${ }^{* *} P<0.01$ (one-way analysis of variance). ERG, electroretinography; HET, heterozygous; MUT, mutant; pSTR, positive scotopic threshold response; WT, wild-type. in the $\triangle 4 C 4-C 5$ mice, ${ }^{52,91}$ we tested the expression of $T G F B 1$, $T G F B 2$, and $T G F B 3$ in mice of all three genotypes. Consistent with earlier reports, ${ }^{35,41}$ we found $T G F B 2$ to be the most highly expressed isoform in the retina and the optic nerve head, but there were no significant differences in TGFB2 expression between the three genotypes. The expression of TGFB1 was higher in MUT retinas than in WT and HET retinas $(P<0.01$, one-way analysis of variance) (Figure $12 \mathrm{~A})$, and the expression level of TGFB3 was lower in HET and MUT optic nerves than in WT optic nerves $(P<0.01$, oneway analysis of variance) (Figure 12B).

In the retinas (Figure 12C), but not the optic nerves, of WT, HET, and MUT mice 1 month after microbead injection, the expression of $C D K N 2 B$ was down-regulated $(P<0.01, t$-test). All $T G F B$ isoforms were down-regulated variably in retinas and optic nerves after microbead injection, but the effect was most pronounced for TGFB3 $(P<0.01, t$-test) (Figure 12, D and $E)$. No obvious differences were found in the degree of down-regulation among different genotypes.

\section{Discussion}

Several GWASs have identified glaucoma-associated SNPs in a hotspot on human chromosome 9p21.3 that has also been found in connection with other diseases. ${ }^{20,25,30}$ In particular, it appears that minor allele for SNPs in $C D K N 2 B-A S$, coding for the long, noncoding RNA, confer relative resistance to POAG. ${ }^{14}$ However, the mechanism is not yet clear. Here, we used a transgenic mouse in which part of murine chromosome 4, including exons 4 to 6 of the $A K 148321$ gene, is deleted. This mouse strain is at present the best animal model to investigate the influence of genes in this locus on glaucoma. However, there are important caveats. First, it is not currently known whether murine $A K 148321$ is functionally equivalent to the human $C D K N 2 B-A S$. Second, the $70-\mathrm{kB}$ deletion on murine chromosome 4 not only eliminates parts of the AK148321 gene but also regulatory elements that are required for the normal expression of the protein-coding genes in the INK4 locus. ${ }^{51}$ This mouse strain therefore does not allow one to directly assess the importance of the noncoding RNA for glaucoma. Finally, in the MUT state, the mice display persistent hyperplastic primary vitreous, ${ }^{52-54}$ making them more difficult to study and less desirable for glaucoma research.

We found no obvious histologic abnormalities of the neural retina in either HET or MUT mice. In particular, the number of ganglion cells was normal compared with WT mice. Functionally, as tested by ERG and optokinetic reflex measurement, WT and HET mice were indistinguishable. The ERG amplitudes and visual acuity of MUT mice are reduced, but our data are consistent with the interpretation that the defect lies not in the retina itself but in the lens opacity and the retrolental tissue. This is most clearly 
A

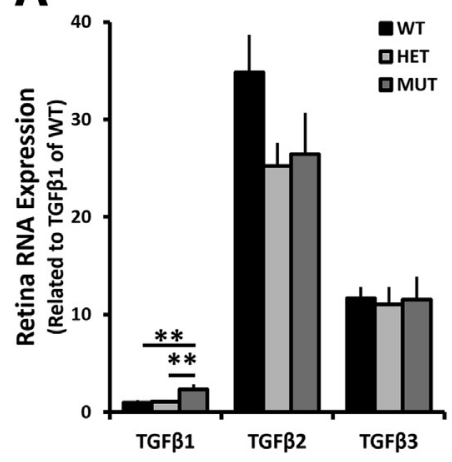

B

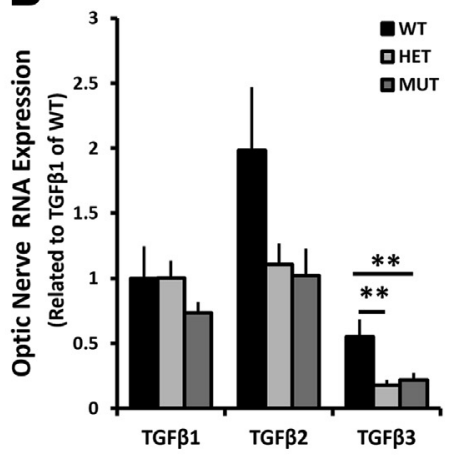

C

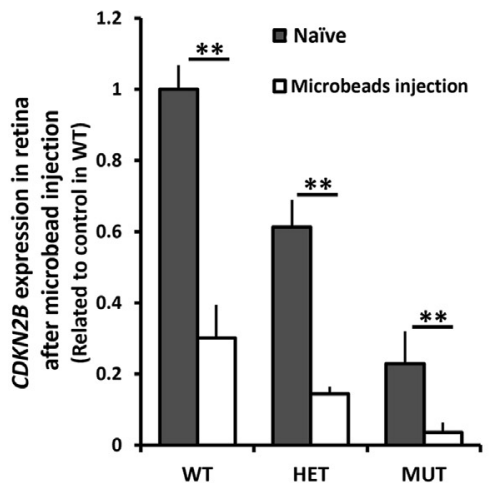

D

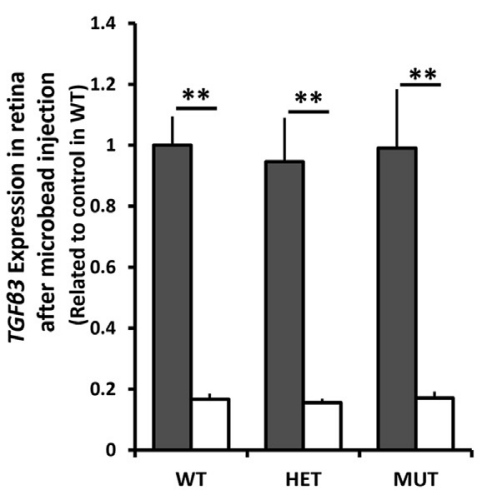

E

Figure 12 Expression of TGFB and CDKN2B after microbead injection. A: In retina tissue, expression level of TGFB1 are increased in MUT eyes compared with WT and HET. B: In optic nerve tissue, expression levels of TGFB3 in HET and MUT are decreased compared with WT. C: Expression levels of CDKN2B are down-regulated after microbead injection in retina tissue. Expression levels of TGFB3 are down-regulated after microbead injection in retina (D) and optic nerve (E) tissues. Data are expressed as means \pm SD. $n=3$ eyes in microbead-injected group and $n=5$ in naive group per genotype. ${ }^{* *} P<0.01$, one-way analysis of variance $(\mathbf{A}$ and $\mathbf{B}) ;{ }^{*} P<0.01, t$-test $(\mathbf{C}-\mathbf{E})$. HET, heterozygous; MUT, mutant; WT, wild-type.

demonstrated by the observation that some MUT mice showed only a mild manifestation of persistent hyperplastic primary vitreous and had near-normal visual acuity. The expression levels of $C D K N 2 B$ are reduced in the retina and optic nerve of MUT and HET mice (Figure 4); similar to what was described for heart tissue. ${ }^{51}$ Taken together, our data indicate that neither the partial deletion of $A K 148321$ nor the down-regulation of $C D K N 2 B$ has a significant negative effect on ganglion cell function, at least under normal conditions.

We found signs of glial reactivity both in the retina and the optic nerve in MUT mice. The Müller cell and microglial reactivity in the retina may be due to the fibrovascular tissue behind the lens. The retrolental tissue was often found to be attached to the peripheral retina (Figure 3E). This may lead to traction on the retina that is not severe enough to cause permanent retinal detachment and photoreceptor degeneration, but it is sufficient to cause glial activation in the retina. However, the number of microglial cells in the MUT retinas is also increased compared with WT and HET retinas. An increase in the microglial cell numbers was reported in glaucoma. ${ }^{42,92,93}$ This may be due to mitosis of microglial cells ${ }^{94}$ or to the entry of monocytes/macrophages from the blood stream that are difficult to distinguish from the native microglia. ${ }^{95} C D K N 2 B$ was described as one of those genes that were up-regulated in microglia after treatment with the plant compound 15-methoxypinusolidic acid that is under investigation as a potential inhibitor of neuroinflammation and microglial activation. ${ }^{96}$ The expression levels of $C D K N 2 B$ are reduced significantly in the MUT mice, which may have the opposite effect of inducing microglial activation even without IOP elevation. Microglial activation in the retina and the optic nerve is an early indicator of glaucoma that precedes ganglion cell loss, ${ }^{84,90,93}$ and neuroinflammation plays a role in the pathogenesis of glaucoma. ${ }^{97}$ We therefore asked whether MUT mice would be more sensitive to an elevation of IOP, induced by the injection of microbeads into the anterior chamber. Ganglion cell loss and optic nerve pathology are significantly worse in the MUT mice. A possible explanation is that microglial cells are constitutively activated in MUT retinas and optic nerve heads and require less of an additional stimulus by IOP elevation to acquire a neurotoxic phenotype. If SNPs in the human Ink4 locus have the potential to negatively affect $C D K N 2 B$ (or $C D K N 2 B-A S$ ) expression in retinal and optic nerve microglia, it could be speculated that even a moderate elevation of IOP causes neuroinflammation in the affected patients and increases the risk of ganglion cell axon damage. 
This might explain why particularly normal-tension glaucoma is associated with SNPs in chromosome 9p21.3. ${ }^{10,14,24,25}$

The TGF- $\beta 1$ pathway was found to be activated in several models of glaucoma ${ }^{43-45,48}$ and traumatic optic nerve damage. ${ }^{47}$ We were therefore surprised that $T G F B 1$ was not up-regulated after microbead injection. A possible explanation may be that a significant up-regulation of $T G F B 1$ was observed in a rat model of ocular hypertension only when considerable damage to the optic nerve had occurred (optic nerve grade 5), ${ }^{44}$ and the injury to the nerve in our cohort of microbead-injected eyes may not have been sufficient to induce up-regulation. We did observe a pronounced downregulation of $T G F B 3$ in the retina and optic nerve after microbead injection, although no differences were found between the genotypes.

Interestingly, in the MUT mice some ganglion cell loss also occurs in the uninjected contralateral eye. This is not normally observed in mouse models of ocular hypertension, ${ }^{98}$ and neither did we find it in the WT and HET mice. Microglial activation in the contralateral eye was described before, ${ }^{88}$ but the mechanism is as yet unclear. Several studies have reported that unilateral intravitreal injections of bevacizumab (an antivascular endothelial growth factor antibody used for the treatment of age-related macular degeneration) also have therapeutic effects on the contralateral eye. This effect is assumed to occur because some of the antibody escapes into the general circulation and reaches the fellow eye. ${ }^{99}$ A similar mechanism may be at work in the MUT eyes after microbead injection. Reactive glial cells in the optic nerve secrete a variety of factors that may lead to increased microglial activation, inflammation, or macrophage entry in the contralateral eye, such as colony-stimulating factor 2 , and chemokine C-X-C motif ligand $1 .^{47}$

\section{Conclusion}

Mutations in the glaucoma-susceptibility locus on chromosome 9p21.3 may predispose to increased vulnerability of ganglion cells to IOP at least partly by a stronger activation of microglia in the retina and the optic nerve. It would be interesting to test whether glaucoma patients bearing the high-risk alleles show signs of increased activation of microglia.

\section{Acknowledgments}

We thank Drs. Daniel Sun, Hee Joo Choi, and Rui Wang for help with ERG, optokinetic reflex, and quantitative PCR; Dr. Joseph Arboleda-Velasquez for helpful discussions of blood vessel labeling and the morphology of retinal blood vessels; Philip Seifert for help with whole-eye sectioning and optic nerve PPD staining; Oscar Morales for assistance with OCT; and Drs. Janey Wiggs and Richard Masland for critically reading the manuscript.

\section{Supplemental Data}

Supplemental material for this article can be found at http://dx.doi.org/10.1016/j.ajpath.2015.11.026.

\section{References}

1. Souzeau E, Goldberg I, Healey PR, Mills RA, Landers J, Graham SL, Grigg JR, Usher B, Straga T, Crawford A, Casson RJ, Morgan WH, Ruddle JB, Coote MA, White A, Stewart J, Hewitt AW, Mackey DA, Burdon KP, Craig JE: Australian and New Zealand Registry of Advanced Glaucoma: methodology and recruitment. Clin Experiment Ophthalmol 2012, 40:569-575

2. Stone EM, Fingert JH, Alward WL, Nguyen TD, Polansky JR, Sunden SL, Nishimura D, Clark AF, Nystuen A, Nichols BE, Mackey DA, Ritch R, Kalenak JW, Craven ER, Sheffield VC: Identification of a gene that causes primary open angle glaucoma Science 1997, 275:668-670

3. Rezaie T, Child A, Hitchings R, Brice G, Miller L, Coca-Prados M, Heon E, Krupin T, Ritch R, Kreutzer D, Crick RP, Sarfarazi M: Adult-onset primary open-angle glaucoma caused by mutations in optineurin. Science 2002, 295:1077-1079

4. Ramdas WD, van Koolwijk LM, Cree AJ, Janssens AC, Amin N, de Jong PT, Wolfs RC, Gibson J, Kirwan JF, Hofman A, Rivadeneira F, Oostra BA, Uitterlinden AG, Ennis S, Lotery AJ, Lemij HG, Klaver CC, Vingerling JR, Jansonius NM, van Duijn CM: Clinical implications of old and new genes for open-angle glaucoma. Ophthalmology 2011, 118:2389-2397

5. Fan BJ, Wiggs JL: Glaucoma: genes, phenotypes, and new directions for therapy. J Clin Invest 2010, 120:3064-3072

6. Takamoto M, Araie M: Genetics of primary open angle glaucoma. Jpn J Ophthalmol 2014, 58:1-15

7. Burdon KP: Genome-wide association studies in the hunt for genes causing primary open-angle glaucoma: a review. Clin Experiment Ophthalmol 2012, 40:358-363

8. Burdon KP, Macgregor S, Hewitt AW, Sharma S, Chidlow G, Mills RA, Danoy P, Casson R, Viswanathan AC, Liu JZ, Landers J, Henders AK, Wood J, Souzeau E, Crawford A, Leo P, Wang JJ, Rochtchina E, Nyholt DR, Martin NG, Montgomery GW, Mitchell P, Brown MA, Mackey DA, Craig JE: Genome-wide association study identifies susceptibility loci for open angle glaucoma at TMCO1 and CDKN2B-AS1. Nat Genet 2011, 43:574-578

9. Burdon KP, Mitchell P, Lee A, Healey PR, White AJ, Rochtchina E, Thomas PB, Wang JJ, Craig JE: Association of open-angle glaucoma loci with incident glaucoma in the Blue Mountains Eye Study. Am J Ophthalmol 2015, 159:31-36.e1

10. Nakano M, Ikeda Y, Tokuda Y, Fuwa M, Omi N, Ueno M, Imai K, Adachi H, Kageyama M, Mori K, Kinoshita S, Tashiro K: Common variants in CDKN2B-AS1 associated with optic-nerve vulnerability of glaucoma identified by genome-wide association studies in Japanese. PLoS One 2012, 7:e33389

11. Osman W, Low SK, Takahashi A, Kubo M, Nakamura Y: A genomewide association study in the Japanese population confirms 9p21 and $14 \mathrm{q} 23$ as susceptibility loci for primary open angle glaucoma. Hum Mol Genet 2012, 21:2836-2842

12. Ramdas WD, van Koolwijk LM, Ikram MK, Jansonius NM, de Jong PT, Bergen AA, Isaacs A, Amin N, Aulchenko YS, Wolfs RC, Hofman A, Rivadeneira F, Oostra BA, Uitterlinden AG, Hysi P, Hammond CJ, Lemij HG, Vingerling JR, Klaver CC, van Duijn CM: A genome-wide association study of optic disc parameters. PLoS Genet 2010, 6:e1000978

13. Wiggs JL, Hauser MA, Abdrabou W, Allingham RR, Budenz DL, Delbono E, Friedman DS, Kang JH, Gaasterland D, Gaasterland T, Lee RK, Lichter PR, Loomis S, Liu Y, McCarty C, Medeiros FA, Moroi SE, Olson LM, Realini A, Richards JE, Rozsa FW, 
Schuman JS, Singh K, Stein JD, Vollrath D, Weinreb RN, Wollstein G, Yaspan BL, Yoneyama S, Zack D, Zhang K, PericakVance M, Pasquale LR, Haines JL: The NEIGHBOR consortium primary open-angle glaucoma genome-wide association study: rationale, study design, and clinical variables. J Glaucoma 2013, 22: $517-525$

14. Wiggs JL, Yaspan BL, Hauser MA, Kang JH, Allingham RR, Olson LM, et al: Common variants at 9p21 and 8q22 are associated with increased susceptibility to optic nerve degeneration in glaucoma. PLoS Genet 2012, 8:e1002654

15. Sundaresan P, Simpson DA, Sambare C, Duffy S, Lechner J, Dastane A, Dervan EW, Vallabh N, Chelerkar V, Deshpande M, O'Brien C, McKnight AJ, Willoughby CE: Whole-mitochondrial genome sequencing in primary open-angle glaucoma using massively parallel sequencing identifies novel and known pathogenic variants. Genet Med 2015, 17:279-284

16. Iglesias AI, Springelkamp H, van der Linde H, Severijnen LA, Amin N, Oostra B, Kockx CE, van den Hout MC, van Ijcken WF, Hofman A, Uitterlinden AG, Verdijk RM, Klaver CC, Willemsen R, van Duijn CM: Exome sequencing and functional analyses suggest that SIX6 is a gene involved in an altered proliferation-differentiation balance early in life and optic nerve degeneration at old age. Hum Mol Genet 2014, 23:1320-1332

17. Chen Y, Lin Y, Vithana EN, Jia L, Zuo X, Wong TY, Chen LJ, Zhu X, Tam PO, Gong B, Qian S, Li Z, Liu X, Mani B, Luo Q, Guzman C, Leung CK, Li X, Cao W, Yang Q, Tham CC, Cheng Y, Zhang X, Wang N, Aung T, Khor CC, Pang CP, Sun X, Yang Z: Common variants near ABCA1 and in PMM2 are associated with primary open-angle glaucoma. Nat Genet 2014, 46: $1115-1119$

18. Gharahkhani P, Burdon KP, Fogarty R, Sharma S, Hewitt AW, Martin S, et al: Common variants near ABCA1, AFAP1 and GMDS confer risk of primary open-angle glaucoma. Nat Genet 2014, 46: $1120-1125$

19. Li Z, Allingham RR, Nakano M, Jia L, Chen Y, Ikeda Y, et al: A common variant near TGFBR3 is associated with primary open angle glaucoma. Hum Mol Genet 2015, 24:3880-3892

20. Ng SK, Casson RJ, Burdon KP, Craig JE: Chromosome 9p21 primary open-angle glaucoma susceptibility locus: a review. Clin Experiment Ophthalmol 2014, 42:25-32

21. Kwon YH, Fingert JH, Kuehn MH, Alward WL: Primary open-angle glaucoma. N Engl J Med 2009, 360:1113-1124

22. Fan BJ, Wang DY, Pasquale LR, Haines JL, Wiggs JL: Genetic variants associated with optic nerve vertical cup-to-disc ratio are risk factors for primary open angle glaucoma in a US Caucasian population. Invest Ophthalmol Vis Sci 2011, 52:1788-1792

23. Cao D, Jiao X, Liu X, Hennis A, Leske MC, Nemesure B, Hejtmancik JF: CDKN2B polymorphism is associated with primary open-angle glaucoma (POAG) in the Afro-Caribbean population of Barbados, West Indies. PLoS One 2012, 7:e39278

24. Burdon KP, Crawford A, Casson RJ, Hewitt AW, Landers J, Danoy P, Mackey DA, Mitchell P, Healey PR, Craig JE: Glaucoma risk alleles at CDKN2B-AS1 are associated with lower intraocular pressure, normal-tension glaucoma, and advanced glaucoma. Ophthalmology 2012, 119:1539-1545

25. Pasquale LR, Loomis SJ, Kang JH, Yaspan BL, Abdrabou W, Budenz DL, Chen TC, Delbono E, Friedman DS, Gaasterland D, Gaasterland T, Grosskreutz CL, Lee RK, Lichter PR, Liu Y, McCarty CA, Moroi SE, Olson LM, Realini T, Rhee DJ, Schuman JS, Singh K, Vollrath D, Wollstein G, Zack DJ, Allingham RR, PericakVance MA, Weinreb RN, Zhang K, Hauser MA, Richards JE, Haines JL, Wiggs JL: CDKN2B-AS1 genotype-glaucoma feature correlations in primary open-angle glaucoma patients from the United States. Am J Ophthalmol 2013, 155:342-353.e5

26. Stone S, Jiang P, Dayananth P, Tavtigian SV, Katcher H, Parry D, Peters G, Kamb A: Complex structure and regulation of the P16 (MTS1) locus. Cancer Res 1995, 55:2988-2994
27. Pasmant E, Laurendeau I, Heron D, Vidaud M, Vidaud D, Bieche I: Characterization of a germ-line deletion, including the entire INK4/ARF locus, in a melanoma-neural system tumor family: identification of ANRIL, an antisense noncoding RNA whose expression coclusters with ARF. Cancer Res 2007, 67:3963-3969

28. Hannon GJ, Beach D: p15INK4B is a potential effector of TGF-betainduced cell cycle arrest. Nature 1994, 371:257-261

29. Seoane J, Pouponnot C, Staller P, Schader M, Eilers M, Massague J: TGFbeta influences Myc, Miz-1 and Smad to control the CDK inhibitor p15INK4b. Nat Cell Biol 2001, 3:400-408

30. Pasmant E, Sabbagh A, Vidaud M, Bieche I: ANRIL, a long, noncoding RNA, is an unexpected major hotspot in GWAS. FASEB J 2011, 25:444-448

31. Hannou SA, Wouters K, Paumelle R, Staels B: Functional genomics of the CDKN2A/B locus in cardiovascular and metabolic disease: what have we learned from GWASs? Trends Endocrinol Metab 2015, 26:176-184

32. Congrains A, Kamide K, Ohishi M, Rakugi H: ANRIL: molecular mechanisms and implications in human health. Int J Mol Sci 2013, $14: 1278-1292$

33. Burd CE, Jeck WR, Liu Y, Sanoff HK, Wang Z, Sharpless NE: Expression of linear and novel circular forms of an INK4/ARFassociated non-coding RNA correlates with atherosclerosis risk. PLoS Genet 2010, 6:e1001233

34. Folkersen L, Kyriakou T, Goel A, Peden J, Malarstig A, PaulssonBerne G, Hamsten A, Hugh W, Franco-Cereceda A, Gabrielsen A, Eriksson P; PROCARDIS consortia: Relationship between CAD risk genotype in the chromosome 9p21 locus and gene expression. Identification of eight new ANRIL splice variants. PLoS One 2009, 4: e7677

35. Pasquale LR, Dorman-Pease ME, Lutty GA, Quigley HA, Jampel HD: Immunolocalization of TGF-beta 1, TGF-beta 2, and TGF-beta 3 in the anterior segment of the human eye. Invest Ophthalmol Vis Sci 1993, 34:23-30

36. Fuchshofer R, Tamm ER: The role of TGF-beta in the pathogenesis of primary open-angle glaucoma. Cell Tissue Res 2012, 347: 279-290

37. Agarwal P, Daher AM, Agarwal R: Aqueous humor TGF-beta2 levels in patients with open-angle glaucoma: a meta-analysis. Mol Vis 2015, 21:612-620

38. Min SH, Lee TI, Chung YS, Kim HK: Transforming growth factorbeta levels in human aqueous humor of glaucomatous, diabetic and uveitic eyes. Korean J Ophthalmol 2006, 20:162-165

39. Ozcan AA, Ozdemir N, Canataroglu A: The aqueous levels of TGFbeta2 in patients with glaucoma. Int Ophthalmol 2004, 25:19-22

40. Picht G, Welge-Luessen U, Grehn F, Lutjen-Drecoll E: Transforming growth factor beta 2 levels in the aqueous humor in different types of glaucoma and the relation to filtering bleb development. Graefes Arch Clin Exp Ophthalmol 2001, 239:199-207

41. Pena JD, Taylor AW, Ricard CS, Vidal I, Hernandez MR: Transforming growth factor beta isoforms in human optic nerve heads. Br J Ophthalmol 1999, 83:209-218

42. Yuan L, Neufeld AH: Activated microglia in the human glaucomatous optic nerve head. J Neurosci Res 2001, 64:523-532

43. Johnson EC, Doser TA, Cepurna WO, Dyck JA, Jia L, Guo Y, Lambert WS, Morrison JC: Cell proliferation and interleukin-6-type cytokine signaling are implicated by gene expression responses in early optic nerve head injury in rat glaucoma. Invest Ophthalmol Vis Sci 2011, 52:504-518

44. Johnson EC, Jia L, Cepurna WO, Doser TA, Morrison JC: Global changes in optic nerve head gene expression after exposure to elevated intraocular pressure in a rat glaucoma model. Invest Ophthalmol Vis Sci 2007, 48:3161-3177

45. Howell GR, Macalinao DG, Sousa GL, Walden M, Soto I, Kneeland SC, Barbay JM, King BL, Marchant JK, Hibbs M, Stevens B, Barres BA, Clark AF, Libby RT, John SW: Molecular clustering identifies complement and endothelin induction as early 
events in a mouse model of glaucoma. J Clin Invest 2011, 121 $1429-1444$

46. Howell GR, Walton DO, King BL, Libby RT, John SW: Datgan, a reusable software system for facile interrogation and visualization of complex transcription profiling data. BMC Genomics 2011, 12:429

47. Qu J, Jakobs TC: The time course of gene expression during reactive gliosis in the optic nerve. PLoS One 2013, 8:e67094

48. Jakobs TC: Differential gene expression in glaucoma. Cold Spring Harb Perspect Med 2014, 4:a020636

49. Harismendy O, Notani D, Song $X$, Rahim NG, Tanasa B, Heintzman N, Ren B, Fu XD, Topol EJ, Rosenfeld MG, Frazer KA: 9p21 DNA variants associated with coronary artery disease impair interferon-gamma signalling response. Nature 2011, 470:264-268

50. Zhang EB, Kong R, Yin DD, You LH, Sun M, Han L, Xu TP, Xia R, Yang JS, De W, Chen J: Long noncoding RNA ANRIL indicates a poor prognosis of gastric cancer and promotes tumor growth by epigenetically silencing of miR-99a/miR-449a. Oncotarget 2014, 5: 2276-2292

51. Visel A, Zhu Y, May D, Afzal V, Gong E, Attanasio C, Blow MJ, Cohen JC, Rubin EM, Pennacchio LA: Targeted deletion of the 9p21 non-coding coronary artery disease risk interval in mice. Nature 2010 , 464:409-412

52. Zheng Y, Devitt C, Liu J, Mei J, Skapek SX: A distant, cis-acting enhancer drives induction of Arf by Tgfbeta in the developing eye. Dev Biol 2013, 380:49-57

53. Martin AC, Thornton JD, Liu J, Wang X, Zuo J, Jablonski MM, Chaum E, Zindy F, Skapek SX: Pathogenesis of persistent hyperplastic primary vitreous in mice lacking the arf tumor suppressor gene. Invest Ophthalmol Vis Sci 2004, 45:3387-3396

54. Silva RL, Thornton JD, Martin AC, Rehg JE, Bertwistle D, Zindy F, Skapek SX: Arf-dependent regulation of Pdgf signaling in perivascular cells in the developing mouse eye. EMBO J 2005, 24: 2803-2814

55. Chidlow G, Wood JP, Sharma S, Dimasi DP, Burdon KP, Casson RJ, Craig JE: Ocular expression and distribution of products of the POAG-associated chromosome 9p21 gene region. PLoS One 2013, 8: e75067

56. Lye-Barthel M, Sun D, Jakobs TC: Morphology of astrocytes in a glaucomatous optic nerve. Invest Ophthalmol Vis Sci 2013, 54: 909-917

57. Prusky GT, Alam NM, Beekman S, Douglas RM: Rapid quantification of adult and developing mouse spatial vision using a virtual optomotor system. Invest Ophthalmol Vis Sci 2004, 45 $4611-4616$

58. Douglas RM, Alam NM, Silver BD, McGill TJ, Tschetter WW, Prusky GT: Independent visual threshold measurements in the two eyes of freely moving rats and mice using a virtual-reality optokinetic system. Vis Neurosci 2005, 22:677-684

59. Chen J, Qian H, Horai R, Chan CC, Caspi RR: Use of optical coherence tomography and electroretinography to evaluate retinal pathology in a mouse model of autoimmune uveitis. PLoS One 2013, 8:e63904

60. Fortune B, Bui BV, Morrison JC, Johnson EC, Dong J, Cepurna WO, Jia L, Barber S, Cioffi GA: Selective ganglion cell functional loss in rats with experimental glaucoma. Invest Ophthalmol Vis Sci 2004, 45:1854-1862

61. Sappington RM, Carlson BJ, Crish SD, Calkins DJ: The microbead occlusion model: a paradigm for induced ocular hypertension in rats and mice. Invest Ophthalmol Vis Sci 2010, 51:207-216

62. Chen H, Wei X, Cho KS, Chen G, Sappington R, Calkins DJ, Chen DF: Optic neuropathy due to microbead-induced elevated intraocular pressure in the mouse. Invest Ophthalmol Vis Sci 2011, $52: 36-44$

63. Pease ME, Cone FE, Gelman S, Son JL, Quigley HA: Calibration of the TonoLab tonometer in mice with spontaneous or experimental glaucoma. Invest Ophthalmol Vis Sci 2011, 52:858-864
64. Sun D, Lye-Barthel M, Masland RH, Jakobs TC: The morphology and spatial arrangement of astrocytes in the optic nerve head of the mouse. J Comp Neurol 2009, 516:1-19

65. Choi HJ, Sun D, Jakobs TC: Astrocytes in the optic nerve head express putative mechanosensitive channels. Mol Vis 2015, 21 749-766

66. Perez de Lara MJ, Santano C, Guzman-Aranguez A, Valiente-Soriano FJ, Aviles-Trigueros M, Vidal-Sanz M, de la Villa P, Pintor J: Assessment of inner retina dysfunction and progressive ganglion cell loss in a mouse model of glaucoma. Exp Eye Res 2014, 122:40-49

67. Fu CT, Sretavan D: Involvement of EphB/Ephrin-B signaling in axonal survival in mouse experimental glaucoma. Invest Ophthalmol Vis Sci 2012, 53:76-84

68. Jia L, Cepurna WO, Johnson EC, Morrison JC: Patterns of intraocular pressure elevation after aqueous humor outflow obstruction in rats. Invest Ophthalmol Vis Sci 2000, 41:1380-1385

69. Cone FE, Gelman SE, Son JL, Pease ME, Quigley HA: Differential susceptibility to experimental glaucoma among 3 mouse strains using bead and viscoelastic injection. Exp Eye Res 2010, 91:415-424

70. Lee BL, Wilson MR; Ocular Hypertension Treatment Study (OHTS): Ocular Hypertension Treatment Study (OHTS) commentary. Curr Opin Ophthalmol 2003, 14:74-77

71. Manni G, Oddone F, Parisi V, Tosto A, Centofanti M: Intraocular pressure and central corneal thickness. Prog Brain Res 2008, 173: $25-30$

72. Quigley HA: Glaucoma. Lancet 2011, 377:1367-1377

73. Helgadottir A, Thorleifsson G, Manolescu A, Gretarsdottir S, Blondal T, Jonasdottir A, Sigurdsson A, Baker A, Palsson A, Masson G Gudbjartsson DF, Magnusson KP, Andersen K, Levey AI, Backman VM, Matthiasdottir S, Jonsdottir T, Palsson S, Einarsdottir H, Gunnarsdottir S, Gylfason A, Vaccarino V, Hooper WC, Reilly MP, Granger CB, Austin H, Rader DJ, Shah SH, Quyyumi AA, Gulcher JR, Thorgeirsson G, Thorsteinsdottir U, Kong A, Stefansson K: A common variant on chromosome 9p21 affects the risk of myocardial infarction. Science 2007, 316:1491-1493

74. McPherson R, Pertsemlidis A, Kavaslar N, Stewart A, Roberts R, Cox DR, Hinds DA, Pennacchio LA, Tybjaerg-Hansen A, Folsom AR, Boerwinkle E, Hobbs HH, Cohen JC: A common allele on chromosome 9 associated with coronary heart disease. Science 2007, 316:1488-1491

75. Samulowitz U, Kuhn A, Brachtendorf G, Nawroth R, Braun A, Bankfalvi A, Bocker W, Vestweber D: Human endomucin: distribution pattern, expression on high endothelial venules, and decoration with the MECA-79 epitope. Am J Pathol 2002, 160:1669-1681

76. Ernst C, Christie BR: Isolectin-IB 4 as a vascular stain for the study of adult neurogenesis. J Neurosci Methods 2006, 150:138-142

77. Saszik SM, Robson JG, Frishman LJ: The scotopic threshold response of the dark-adapted electroretinogram of the mouse. J Physiol 2002, 543:899-916

78. Bui BV, Fortune B: Ganglion cell contributions to the rat full-field electroretinogram. J Physiol 2004, 555:153-173

79. Holcombe DJ, Lengefeld N, Gole GA, Barnett NL: Selective inner retinal dysfunction precedes ganglion cell loss in a mouse glaucoma model. Br J Ophthalmol 2008, 92:683-688

80. Porciatti V: Electrophysiological assessment of retinal ganglion cell function. Exp Eye Res 2015, 141:164-170

81. Hernandez MR: The optic nerve head in glaucoma: role of astrocytes in tissue remodeling. Prog Retin Eye Res 2000, 19:297-321

82. Linser PJ, Sorrentino M, Moscona AA: Cellular compartmentalization of carbonic anhydrase-C and glutamine synthetase in developing and mature mouse neural retina. Brain Res 1984, 315:65-71

83. Inman DM, Horner PJ: Reactive nonproliferative gliosis predominates in a chronic mouse model of glaucoma. Glia 2007, 55: 942-953

84. Bosco A, Steele MR, Vetter ML: Early microglia activation in a mouse model of chronic glaucoma. J Comp Neurol 2011, 519: $599-620$ 
85. Nimmerjahn A, Kirchhoff F, Helmchen F: Resting microglial cells are highly dynamic surveillants of brain parenchyma in vivo. Science 2005, 308:1314-1318

86. Astafurov K, Dong CQ, Panagis L, Kamthan G, Ren L, Rozenboym A, Perera TD, Coplan JD, Danias J: Complement expression in the retina is not influenced by short-term pressure elevation. Mol Vis 2014, 20:140-152

87. Morgan JE, Tribble JR: Microbead models in glaucoma. Exp Eye Res 2015, 141:9-14

88. Rojas B, Gallego BI, Ramirez AI, Salazar JJ, de Hoz R, ValienteSoriano FJ, Aviles-Trigueros M, Villegas-Perez MP, Vidal-Sanz M, Trivino A, Ramirez JM: Microglia in mouse retina contralateral to experimental glaucoma exhibit multiple signs of activation in all retinal layers. J Neuroinflammation 2014, 11:133

89. Gallego BI, Salazar JJ, de Hoz R, Rojas B, Ramirez AI, SalinasNavarro M, Ortin-Martinez A, Valiente-Soriano FJ, AvilesTrigueros M, Villegas-Perez MP, Vidal-Sanz M, Trivino A, Ramirez JM: IOP induces upregulation of GFAP and MHC-II and microglia reactivity in mice retina contralateral to experimental glaucoma. J Neuroinflammation 2012, 9:92

90. Bosco A, Romero CO, Breen KT, Chagovetz AA, Steele MR, Ambati BK, Vetter ML: Neurodegeneration severity can be predicted from early microglia alterations monitored in vivo in a mouse model of chronic glaucoma. Dis Model Mech 2015, 8:443-455

91. Loinard C, Basatemur G, Masters L, Baker L, Harrison J, Figg N, Vilar J, Sage AP, Mallat Z: Deletion of chromosome 9p21 noncoding cardiovascular risk interval in mice alters Smad2 signaling and promotes vascular aneurysm. Circ Cardiovasc Genet 2014, 7: 799-805
92. Naskar R, Wissing M, Thanos S: Detection of early neuron degeneration and accompanying microglial responses in the retina of a rat model of glaucoma. Invest Ophthalmol Vis Sci 2002, 43:2962-2968

93. Bosco A, Crish SD, Steele MR, Romero CO, Inman DM, Horner PJ, Calkins DJ, Vetter ML: Early reduction of microglia activation by irradiation in a model of chronic glaucoma. PLoS One 2012, 7:e43602

94. Wohl SG, Schmeer CW, Witte OW, Isenmann S: Proliferative response of microglia and macrophages in the adult mouse eye after optic nerve lesion. Invest Ophthalmol Vis Sci 2010, 51:2686-2696

95. Howell GR, Soto I, Zhu X, Ryan M, Macalinao DG, Sousa GL, Caddle LB, MacNicoll KH, Barbay JM, Porciatti V, Anderson MG, Smith RS, Clark AF, Libby RT, John SW: Radiation treatment inhibits monocyte entry into the optic nerve head and prevents neuronal damage in a mouse model of glaucoma. J Clin Invest 2012, 122:1246-1261

96. Choi Y, Lim SY, Jeong HS, Koo KA, Sung SH, Kim YC: Oligonucleotide microarray analysis of apoptosis induced by 15 -methoxypinusolidic acid in microglial BV2 cells. Br J Pharmacol 2009, 157: $1053-1064$

97. Soto I, Howell GR: The complex role of neuroinflammation in glaucoma. Cold Spring Harb Perspect Med 2014, 4

98. Salinas-Navarro M, Alarcon-Martinez L, Valiente-Soriano FJ, OrtinMartinez A, Jimenez-Lopez M, Aviles-Trigueros M, VillegasPerez MP, de la Villa P, Vidal-Sanz M: Functional and morphological effects of laser-induced ocular hypertension in retinas of adult albino Swiss mice. Mol Vis 2009, 15:2578-2598

99. Nomoto H, Shiraga F, Kuno N, Kimura E, Fujii S, Shinomiya K, Nugent AK, Hirooka K, Baba T: Pharmacokinetics of bevacizumab after topical, subconjunctival, and intravitreal administration in rabbits. Invest Ophthalmol Vis Sci 2009, 50:4807-4813 